http://economix.fr

The universal bank model: Synergy or vulnerability?

Document de Travail

Working Paper

2015-13
Michael Brei

Xi Yang

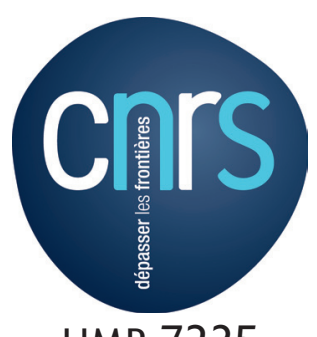

UMR 7235
Université de Paris Ouest Nanterre La Défense (bâtiment G)

200, Avenue de la République 92001 NANTERRE CEDEX

Tél et Fax : 33.(0)1.40.97.59.07 Email :nasam.zaroualete@u-paris10.fr université

Paris Ouest 


\title{
The universal bank model: Synergy or vulnerability? ${ }^{1}$
}

\author{
Michael Brei ${ }^{\mathrm{a}, \mathrm{b}}$ and Xi Yang ${ }^{\mathrm{a}}$
}

April 2015

\begin{abstract}
In this paper we examine empirically the relationship between banks' income diversification, expansion into non-traditional activities and performance. Using detailed information on the U.S. banking sector over the period 2002-12, we investigate whether or not banks' involvement in various business lines has been associated with higher accounting returns and risks. Over the long-term, we find robust evidence that banks' expansion into non-traditional activities has lacked revenue and diversification benefits: overall risks of non-traditional banks have been higher, while returns were not. A higher degree of diversification across traditional and certain non-traditional activities, on the contrary, has been associated with important risk reduction benefits. The effects are non-linear and differ across business lines, which seems to suggest that an optimal mix of banking activities exists.
\end{abstract}

\section{JEL classification: $\mathbf{6 2} 1$}

Keywords: banking, diversification, non-traditional activities, risk, profitability

\footnotetext{
a Université Paris Ouest - Nanterre La Défense, EconomiX-CNRS, 200 Avenue de la République, 92001 Nanterre, France. E-mail addresses: michael.brei@uni-bonn.de (corresponding author); xiyang92@gmail.com

${ }^{\mathrm{b}}$ Sir Arthur Lewis Institute of Social and Economic Studies, The University of the West Indies, Trinidad \& Tobago
}

\footnotetext{
1 The authors would like to thank Michel Boutillier, Elena Dumitrescu, Laurence Scialom, Tatiana Yongoua Tchikanda and the seminar participants of the Financial Intermediation Seminar at University Paris Ouest for valuable and helpful comments. All remaining errors are ours.
} 


\section{Introduction}

In response to the global financial crisis, a number of financial regulators from the advanced economies have implemented or are considering significant modifications in their regulatory framework. The adjustments range from enhancements in capital adequacy (Brei and Gambacorta, 2014) and liquidity requirements (Bech and Keister, 2013) to the mandatory stress-testing of systemically important financial institutions (Bernanke, 2013). Another major shift in banking regulation - albeit much less synchronized across jurisdictions - represents the so-called structural bank reform aimed at reviewing and eventually limiting the permissible scope of activities in which commercial banks are allowed to operate (Gambacorta and van Rixtel, 2013).

The last decades have been marked by important financial innovation and bank deregulation. There was a broad consensus among policymakers that banks should be allowed to offer the full scope of financial services - ranging from traditional bank activities to investment banking or the provision of insurance services. The main argument of the proponents of this line of thought was that the diversification of banking activities, which goes along with the universal bank model, will ultimately enhance banks' economies of scope through revenue and cost synergies (Calomiris, 2000). It was also believed that banks would benefit from risk reductions associated with activity diversification (Wall and Eisenbeis, 1984). Accordingly, universal banks should be favored to narrow banks which would have little economies of scope and less diversified fields of activities.

The conventional wisdom, however, has been questioned, especially so with the onset of the global financial crisis. A number of the major banks have been pushed close to their insolvency caused by a combination of significant increases in asset write downs - originating on banks' loan and trading books - and interruptions in wholesale funding markets. It has been argued that most vulnerable have been those banks that shifted too many resources away from the traditional banking business into complex and hardly understood trading portfolios. According to this view, banks should focus on their core businesses and competencies. In an attempt to insulate depositors and borrowers from such types of risks, a number of governments have started to re-consider their existing models of structural bank regulation putting forth the possibility of a mandatory separation of "commercial banking" from certain "investment banking" activities (Gambacorta and van Rixtel, 2013; FSB, 2014). ${ }^{2}$

The empirical literature on the relationship between activity diversification, profitability and risk in banking has produced mixed evidence. The expansion and diversification across business lines might arguably be associated with improvements in bank profitability and efficiency, as banks find new ways to increase their earning capacity or they accomplish revenue and costs synergies (Vander Vennet, 2002; Drucker and Puri, 2005; Valverde and Fernandez, 2005; Yasuda, 2005; Elsas et al., 2010). ${ }^{3}$ A more

\footnotetext{
${ }^{2}$ See also the Volcker rule, Liikanen report and Vickers report.

${ }^{3}$ For example, providing insurance and asset management services through an existing retail bank branch network might be associated with cost economies of scope. Such cross-selling of products can in turn generate revenue economies of scope implied by consumption complementarities ("one-stop shopping" convenience), which reduce consumers search and transaction costs and increase a bank's ability to underprice competitors.
} 
diversified and wider field of activities, however, might not translate into lower risks, especially if cash flows are positively correlated or if the newly adopted businesses are not well undertaken due to a lack of expertise (Jiménez and Saurina, 2004). Mixing loan portfolios with trading portfolios and other types of activities might just as well increase the size and opaqueness of banks, intensify agency problems across divisions and distort managers' incentives (Lang and Welzel, 1996; Demsetz and Strahan, 1997; Kahn and Winton, 2004; Leaven and Levine, 2007; Boot and Ratnovski, 2012). Indeed there exist a number of studies which suggest that the diversification benefits across traditional and non-traditional activities in banking can be offset by the strong volatility of non-interest income (Allen and Jagtiani, 2000; DeYoung and Roland, 2001; DeYoung and Rice, 2004; Stiroh, 2004; Stiroh and Rumble, 2006; Geyfman and Yeager, 2009; Demirgüç-Kunt and Huizinga, 2010; DeYoung and Torna, 2013).

Against these backdrops, the present study investigates whether or not the universal bank model has been associated with higher risks and returns, using information on the financial statements of more than 10,000 commercial banks and financial holding companies headquartered in the United States over the period 2002-12. In particular we seek to answer the following questions: (i) Do universal banks that offer a broader range of financial services outperform more specialized banks?; (ii) If there are any differences in the performance of universal and specialized banks, which are the activities that explain this divergence?; and (iii) What would have been the optimal mix of banking activities in the United States from a retrospective point of view?

Our empirical analysis has to be careful about the potential interlinkages of banks and holding companies. On the one hand, we have to take into account that many commercial banks in the United States are owned by financial holding companies, which themselves might control other peers in the industry. The financial statements have thus to be aggregated according to the ultimate financial holder. On the other hand, holding companies might own non-financial firms that are not covered in the call reports, implying that we have to augment our data on commercial banks with the financial statements of holding companies. And finally, we have to take into account the large number of mergers and acquisitions that occurred during our sample period, as these events are associated with changes in ownership and business strategies.

The econometric analysis borrows from Stiroh and Rumble (2006) who investigate the relationship between bank performance and activity diversification of US financial holding companies. The authors provide evidence in favor of diversification benefits across banking groups, however, they highlight that such gains have been offset by the exposure to non-interest activities, which have been more volatile and not necessarily more profitable than interest-generating activities. We extend their approach in a number of ways. First, we distinguish between traditional and non-traditional types of non-interest income, rather than considering the two as a homogenous group (DeYoung and Torna, 2013). Second, we allow for a non-linear relationship between bank performance and business orientation (Gambacorta and van Rixtel, 2013). Third, we employ more recent data over a longer time horizon, which means that we can compare and contrast our results to those of Stiroh and Rumble (2006) obtained for the period 1997-2002. And fourth, we investigate the optimal mix of activities for large and small banks using a six-asset portfolio approach applied to banks' financial statements. 
Our main results confirm that banks face a trade-off between the risk/return characteristics of different business lines. In terms of banks' expansion into non-traditional banking activities, we find a rather sobering result for the US banking industry from a long-term perspective: the expansion into the nontraditional spheres of banking has been associated with significant increases in risks across banks that have not been compensated by higher returns. Within banks from a short-term perspective, the overall level of risks still increases with higher non-traditional activities. However, higher returns compensate banks partially for the increase in income volatility. There exist, on the other hand, important risk reduction benefits associated with the diversification of banking activities across traditional and particular types of non-traditional businesses, both across and within banks. The econometric evidence on the effect of diversification on bank profitability is mixed: while higher diversification has been associated with significantly higher returns across banks, we find the opposite within banks. Further sensitivity tests suggest that not all non-traditional activities have been associated with higher levels of risk. For instance, banks' expansion into the underwriting of insurance has been associated with significant improvements in bank profits and risks. Overall, our results suggest that there exists an optimal mix of activities in which banks should be allowed to operate.

The results cast some doubt on the question of why commercial banks have been moving into particular non-traditional activities (Stiroh, 2006; Stiroh and Rumble, 2006; Geyfman and Yeager, 2009; Demirgüç-Kunt and Huizinga, 2010; DeYoung and Torna, 2013). One explanation might be that bank managers have overestimated the benefits of certain activities and underestimated the inherent risks. More specifically, it might be that they have underestimated the conditional correlation of the revenues from different business lines, which eventually reached high levels during the recent financial turmoil. Alternatively, it might be that bank managers have targeted short-term profits and risks rather than the long-term implications of their decisions. Such behavior could be the result of inadequate compensation schemes or other types of incentive distortions that are present in the banking industry (Merton, 1977; Fahri and Tirole, 2012). Finally, it has been argued that the integration of different business lines within a financial conglomerate may exacerbate inefficiencies and incentive distortions, implied by the complexity of the entity or agency problems that arise across divisions (Jensen, 1986; Rime and Stiroh, 2003; Kahn and Winton, 2004; Laeven and Levine, 2007; Schmid and Walter, 2009; Boot, 2011).

The paper is organized as follows. In the next section, we discuss briefly the data and stylized facts on universal banks in the United States. Section 3 presents the econometric approach and discusses the main hypotheses and econometric results. Section 4 summarizes the robustness tests, and Section 5 provides a back-of-the-envelope calculation of the optimal mix of banking activities. The final section concludes. 


\section{Description of the data}

In this study, we investigate data on the financial statements of FDIC-insured banks and bank holding companies augmented with information on mergers and acquisitions. The financial accounts of banks are reported on a consolidated basis, meaning that any majority-owned subsidiary is integrated in the financial statement of the controlling bank. In the US banking industry, however, it is relatively common that - on top - different commercial banks are controlled by a financial holding company. In the context of universal banks, which tend to operate and manage a variety of business lines through separate subsidiary banks, it is thus essential to aggregate the financial statements of individual banks by the ultimate holding company. In doing so, we make sure to capture the entire business activities of large and complex banking groups taking into account the interconnected structure of ownership. The aggregation by the ultimate holding company is also a natural choice in our context, since bank managers presumably make decisions on the entire institution.

The available information allows us to identify whether or not a bank is owned by a bank holding company. It is hereby relatively common that a holding company controls more than one subsidiary bank. For example, the holding company Citigroup INC controls the two national banks Citibank NA (60\% of the BHC's consolidated assets) and Citibank South Dakota NA (10\%), the Edge Corporation Citibank Overseas Investment (22\%), and two small non-deposit trust companies. In what follows, we will focus on the aggregated "pro-forma" financial statements, when banks are controlled by the same holding company, while we use the original financial accounts if banks operate on a stand-alone basis. ${ }^{4}$ As a final precaution, we treat a banking group as a new institution when there is a change in the ownership, because such changes are likely to be associated with structural reorganizations and shifts in business strategies (Stiroh and Rumble, 2006).

In our database, there are recorded 13,397 FDIC-insured banks (mainly commercial and statechartered savings banks) over the period 1995-2012, of which 6,502 entities have been active at end2012 with $\$ 13.6$ trillion of assets. The majority of these banks (82\% of the total) have been controlled by 8,141 holding companies. In other words, the average banking group consisted of one holding company and 1.6 FDIC-insured banks (Wells Fargo controlled with 153 most entities). After excluding banks with a short lifespan and accounting for changes in the ownership, we ended up with 10,360 distinct banking groups (stand-alone and pro-forma) of which 5,700 entities have been active at end2012 with a total of $\$ 12.3$ trillion of assets. ${ }^{5}$

\footnotetext{
${ }^{4}$ The pro-forma statements are calculated by the sum of the individual statements of banks that belong to the same ultimate holder.

${ }^{5}$ We excluded banks with a lifespan of less than 12 quarters. Due to the large number of changes in the ultimate holding company, we required in addition that the aggregated pro-forma bank has been active for at least 12 quarters. We hereby modified the date of the change in the ownership, if the information provided in the call reports differed from the M\&A database, preferring the latter source of information. Finally, foreign-owned banks and banks controlled by non-financial entities have been excluded, because of the lack of data on the holding company.
} 
Universal banks are characterized by a higher degree of activity diversification compared to more concentrated banks. This difference becomes apparent in a bank's income sources: while traditionally banks earned profits from the intermediation of deposits and loans, as summarized by the net interest income, universal banks tend to generate important fractions of their profits from non-interest income sources. These might include revenues from market operations or fees generated by trading, securitization, investment banking, insurance underwriting and sale, or securities brokerage. As can be seen in Figure 1, the non-interest income share in commercial banking in the United States has gradually increased in the period 1995-2007 from 36 to 44 percent of net operating income. This broad trend has, however, largely reversed with the onset of the financial crisis and the increased regulatory scrutiny faced by the banking industry.

Figure 1: Commercial banks' income sources ${ }^{6}$

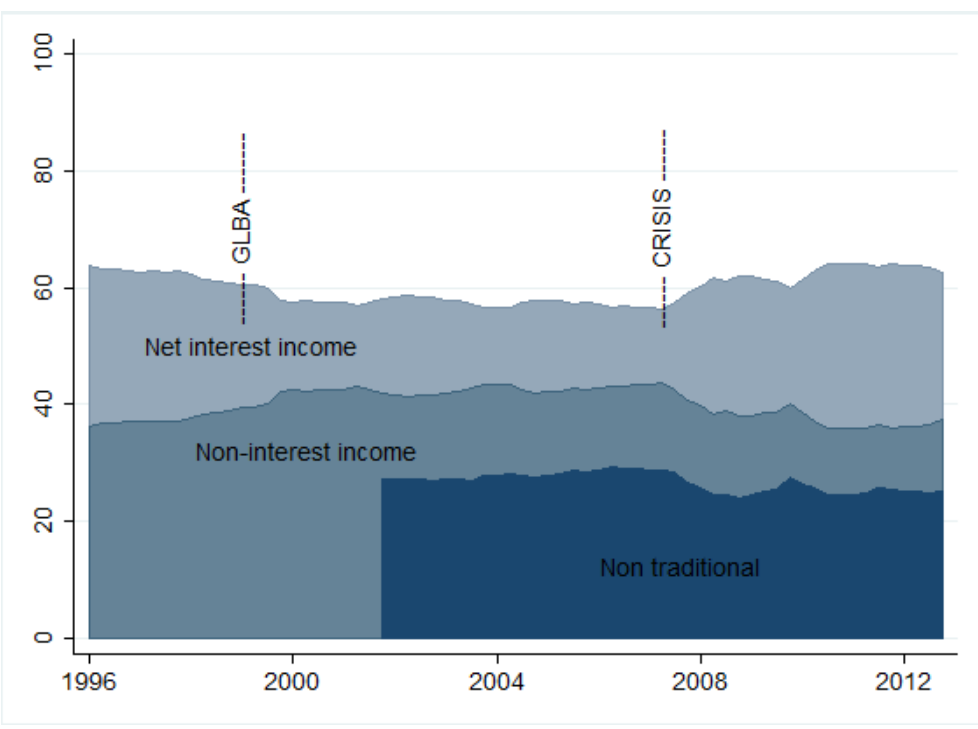

Historically, the universal bank model has been more common in Europe compared to the United States (Calomiris, 1995; Breton and Clerc, 2015). Indeed - in response to the Great Depression - US regulators imposed a strict separation of commercial banking from investment banking that lasted over decades. Only over time, certain activity restrictions have been removed, starting in the late 1980s and culminating in the Gramm-Leach-Bliley Act (GLBA) of 1999, which allowed banks to engage in securities dealing and underwriting, insurance, merchant banking and propriety trading on a bank's own account (Furlong, 2000; DeYoung and Rice, 2004; Avraham et al., 2012).

The adoption of the non-traditional activities has been uneven across banks. While investment banking and securities brokerage complemented naturally the product lines of the major banking groups, the underwriting and sale of insurance proved a profitable business strategy for most banks - independent

\footnotetext{
${ }^{6}$ In percent of net operating income calculated by the sum of net interest income and total non-interest income. Non-interest income from non-traditional activities (information available from Q2/2001 onwards) is defined by the difference between total non-interest income and revenues related to fiduciary and payment $\&$ deposit account services.
} 
of size and clientele. As can be seen in Figure 2, the sources of non-interest income across large and small banks differ remarkably: while traditional activities (fiduciary and payment $\&$ deposit account services) accounted for the major part of non-interest income in the case of small banks, nontraditional activities (trading, investment banking, securities brokerage, insurance, loan servicing and securitization) have been much more important for large banks.

Figure 2: Sources of non-interest income, end- $2007^{7}$

(a) Large banks

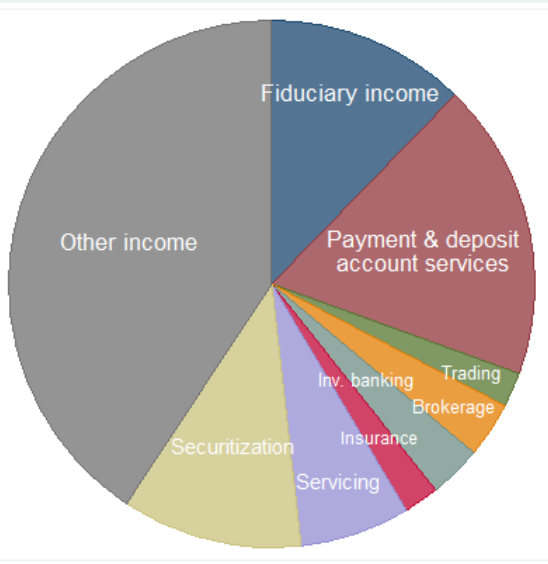

(b) Small banks

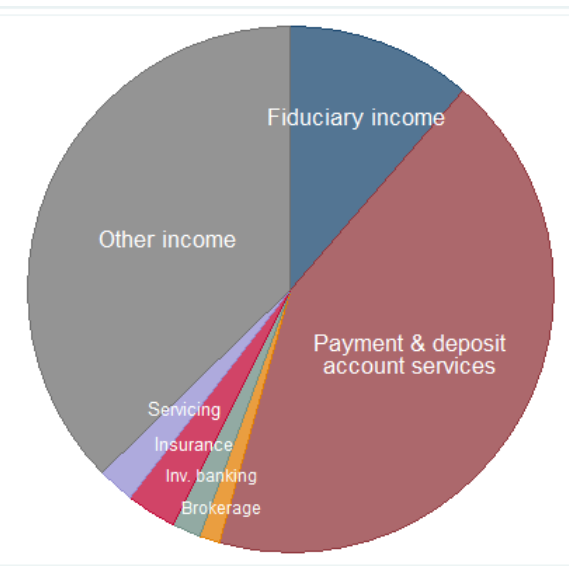

The existing literature does neither provide a unique and unambiguous definition of universal banks, nor is it clear where the distinction between universal and non-traditional banks should be drawn. In what follows, we will investigate three types of banks, all of which could - in principle - be seen as nontraditional and/or universal banks (Geyfman and Yeager, 2009; Elsas et al., 2010; DeYoung and Torna, 2013):

(i) Universal/diversified versus narrow/specialized banks - measured by the degree of income diversification calculated by the Herfindahl-Hirschmann Index (HHI) for the major interest and non-interest income categories: ${ }^{8}$

$$
D I V_{i t}=1-\sum_{j=1}^{N}\left(\frac{I_{i t}^{j}}{O R_{i t}}\right)^{2},
$$

\footnotetext{
${ }^{7}$ In percent of total non-interest income. Large banks have assets in the upper quartile of the distribution of total assets at end-2007, while small banks are the other banks. The "other income" variable represents the category "other non-interest income" discussed in Section 4. For sake of presentation, we added small income categories to other income (venture capital and annuity sales for large banks; venture capital, annuity sales, security brokerage, trading and securitization for small banks).

${ }^{8}$ We have as well experimented with asset diversification. We prefer however this measure, since Fee-for-Service activities are not readily displayed in the balance sheet, as they involve in many cases contingent off-balance sheet positions or intangible assets such as human capital and non-financial assets like information technology (Boyd and Gertler, 1994; Stiroh, 2006).
} 
where $O R_{i t}$ denotes operating income of bank $i$ at time $t$ and $l_{i t}^{j}$ income earned from activity $j$. Operating income is defined by the sum of the different interest income sources, including income on loans, leases, balances due from depository institutions, trading assets, securities, inter-bank lending and other interest income, and non-interest income sources related to fiduciary services, payment \& deposit account services, trading, securitization, loan servicing, venture capital and other non-interest income.

(ii) Non-traditional versus traditional banks - measured by the ratio of the non-traditional part of non-interest income (total non-interest income net of fees related to fiduciary and payment $\&$ deposit account services) over operating income.

(iii) Financial holding companies with non-bank subsidiaries ("FHC-owned banks") versus other banks - defined by banking groups that converted to financial holding companies with nonbank subsidiaries (broker, dealer or insurance), following the enactment of the Gramm-Leach-BlileyAct in 1999.

Table 1 provides summary statistics across the different types of banks. A few patterns emerge. On average, banks with a higher share of non-traditional income, higher degree of income diversification, and FHC-owned banks have been larger in terms of assets than the other banks. While non-traditional banks had - by definition - a higher non-interest income share compared to traditional banks (1.6 and 0.4 percent of assets prior to the crisis), this difference is less important if one compares diversified with specialized banks (1.2 and 0.5 percent). The highest non-interest income share has been recorded by FHC-owned banks (2.0 percent), indicating that there is a certain overlap with the definition of nontraditional banks. As a group, non-traditional, diversified and FHC-owned banks have been more profitable than the other banks prior to the crisis. With the onset of the financial turmoil, bank profitability dropped across all bank types explained by a combination of drops in interest income and increases in provisions and non-interest expenses (especially intangible asset losses). Most affected by the crisis have been non-traditional and specialized banks, while diversified banks seem to have better resisted.

On the asset side, the largest differences are observed at banks that diversified their income sources. For instance, they had with 46 percent of assets a higher share of "liquid" assets (mainly securities) prior to the crisis than the average bank (32 percent). Accordingly, they have been less involved in the traditional lending business with a share of 50 percent of assets compared to an average of 64 percent. There are as well some differences in the composition of loans across banks. For instance, FHC-owned banks have been more exposed to commercial and industrial loans with a share of 10 percent of assets compared to 2 percent for the average bank. On the liability side, the differences are less important. All banks have mainly been financed by costumer deposits with shares well above 70 percent of assets. It appears, however, that FHC-owned banks relied to a larger extent on inter-bank liabilities and wholesale funding.

There are important differences in the off-balance sheet exposures of FHC-owned banks compared to the other banks. For instance, credit commitments amounted to 39 percent of assets prior to the crisis 
compared to an average of 15 percent in the entire banking industry. Another striking difference can be observed for derivatives exposures. FHC-owned banks recorded on average a ratio of outstanding derivatives of 165 percent of assets prior to the crisis compared to an average of 2 percent for all banks. ${ }^{9}$ Lastly, we compare a number of risk indicators. For instance, based on Z-scores, the pre- and post-crisis averages suggest that traditional and diversified banks have been less risky than their nontraditional and more specialized peers.

\section{Econometric strategy}

In this section we examine econometrically the relationship between banks' business strategy and performance. Based on the portfolio choice theory and the empirical investigation of Stiroh and Rumble (2006), we measure bank performance in terms of the observed return and risk of a bank's portfolio - defined here by the return on equity (ROE) and its volatility. While the return on equity is calculated directly from the financial reports as the ratio of annualized net income over total equity, we calculate the volatility (standard deviation) over a bank's lifetime or over four quarterly observations, depending on the econometric approach (between versus within estimator).

It could be argued that the unconditional volatility of profits is not an appropriate measure of bank risk, because financial markets allow banks and investors to diversify and hedge idiosyncratic risks. While this criticism has to be taken seriously, it should be noted that such considerations only hold in an idealized world in which market imperfections and incompleteness are ruled out. Moreover, the return on equity and its volatility are important indicators that are used by regulators, managers and shareholders to assess the performance and soundness of financial institutions. It may also serve as a criterion in performance-based remuneration schemes for bank managers. One could of course examine equity market returns and their implied volatility with the advantage that these indicators are forward-looking and thus a possibly better measure for expected returns and risks, but with the caveat of limiting the study to a much smaller sample of publicly traded and large banks (Stiroh, 2006; Geyfman and Yeager, 2009).

Figure 3 shows the average risk/return profiles across small, medium-sized and large banks over the period 2002-12. For comparison, we show the return on assets and its volatility in the right-hand panel. Over our sample period, the average bank generated a return of 6.2 percent of equity with a standard deviation of 7.1. The relation between returns and risks appears negative in most cases - implying that higher risks have not been necessarily compensated by higher returns in the long-run. The latter finding is similar to Stiroh and Rumble (2006) who find a negative correlation between the average

\footnotetext{
${ }^{9}$ Outstanding derivatives refers to the notional amounts of derivative contracts (futures, forwards, options and swaps) and credit derivatives (credit default swaps, total return swaps and credit options). If one assumes an average conversion factor of 4.5 percent of the notional amount (the average of the Basel conversion factors applied to interest, FX and equity contracts), the "credit equivalent" of the FHC-bank exposures would be 7.4 percent of assets.
} 
profit ratio and volatility over the period 1997-2002, which they interpret as evidence for the presence of negative shocks that lower simultaneously average profits and increase volatility. ${ }^{10}$

Intuitively we can think that, if a bank invests in a traditional loan portfolio $L$ and a non-traditional trading portfolio $T$, then the expected portfolio return, $E\left(R_{P}\right)$, and variance, $V\left(R_{P}\right)$, are given by:

$$
\begin{gathered}
E\left(R_{P}\right)=x E\left(R_{L}\right)+(1-x) E\left(R_{T}\right) \\
V\left(R_{P}\right)=x^{2} V\left(R_{L}\right)+(1-x)^{2} V\left(R_{T}\right)+2 x(1-x) \operatorname{COV}\left(R_{L}, R_{T}\right)
\end{gathered}
$$

where $x$ represents a bank's loan portfolio share in total assets and $\operatorname{COV}\left(R_{L}, R_{T}\right)$ the covariance of the two individual portfolio returns. If a bank invests in a trading portfolio with a higher and more volatile return compared to the loan portfolio, $E\left(R_{T}\right)>E\left(R_{L}\right)$ and $V\left(R_{T}\right)>V\left(R_{L}\right)$, then a bank's performance indicators will be affected in three ways: (i) the expected return of the overall portfolio will increase; (ii) the overall variance will directly increase through the variance term; and (iii) the overall variance will indirectly be affected through the covariance term, depending on the sign and magnitude of the covariance.

Figure 3: Average risk-return profiles of banks, 2002-12 11
a) Return on equity
b) Return on assets
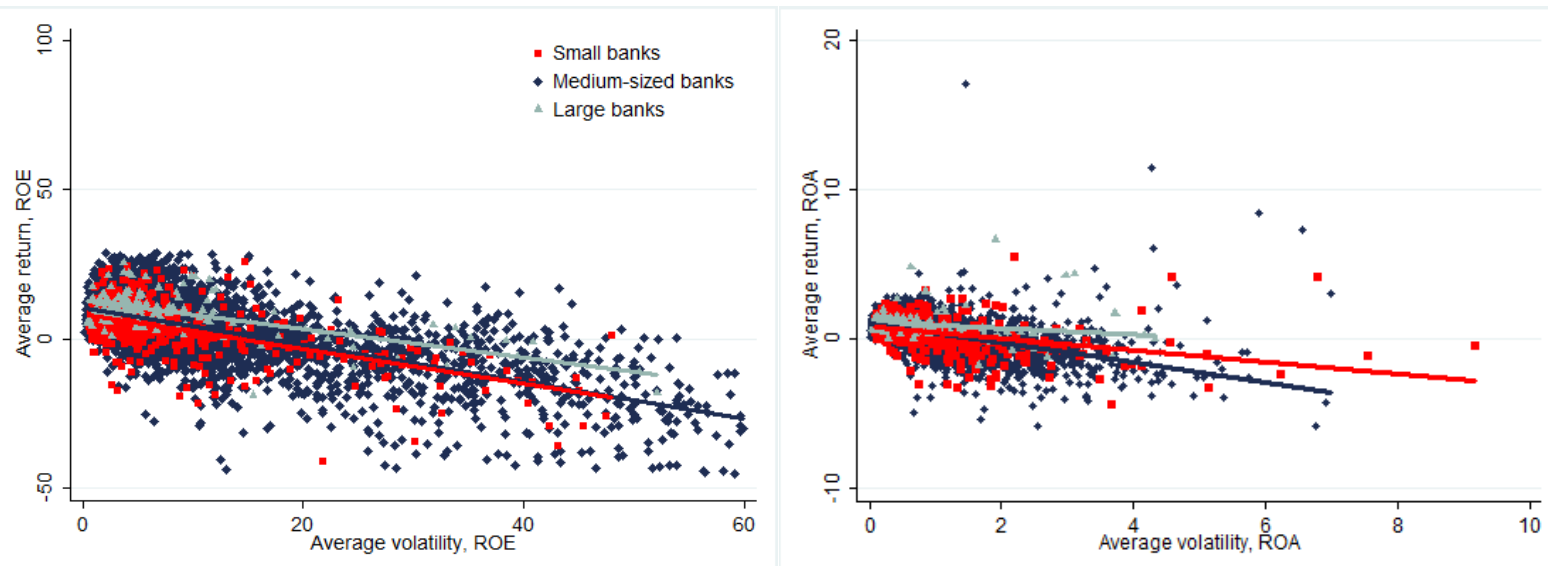

If we knew the expected returns of each individual activity and the variance-covariance matrix, then we could determine the optimal mix of activities, $x^{*}$, depending on a bank's preferences. With our data in hand, however, it is difficult to measure the returns and volatilities of each type of activity, because they involve in many cases the use of services and intangible assets that are not directly visible on the balance sheet. Nevertheless, we can investigate the impact of a broader set of activities on overall bank returns and risks, using a reduced form regression that includes our measures for diversified and

\footnotetext{
${ }^{10}$ The relation between returns and risks has also been negative, when we considered pre-crisis averages.

${ }^{11}$ The Figure shows unweighted averages of the annual return on equity (assets) and its standard deviation over the period 2002-2012. Large banks have average assets in the top two percentiles of the distribution of assets, medium-sized banks have assets between the $10^{\text {th }}$ and $98^{\text {th }}$ percentile, and small banks are the remaining banks $\left(<10^{\text {th }}\right.$ percentile).
} 
non-traditional banks along with other bank characteristics. Moreover, we provide a numerical evaluation of the optimal mix of banking activities using a simple back-of-the-envelope calculation.

Our baseline specification takes the following form:

$$
\begin{aligned}
y_{i t}= & \beta_{0}+\beta_{1} D I V_{i t-1}+\beta_{1}^{*} D I V_{i t-1}^{2}+\beta_{2} N T_{i t-1}+\beta_{2}^{*} N T_{i t-1}^{2}+\delta X_{i t-1}+u_{i t} \\
& \text { with } y_{i t}=R O E_{i t} \text { and } \sigma_{i t}^{R O E}
\end{aligned}
$$

where $D I V_{i t-1}$ and $N T_{i t-1}$ indicate income diversification and the non-traditional income share. The squares of these measures are included to allow for the possibility of non-linear effects of diversification and non-traditional activities on bank returns and risks (Gambacorta and van Rixtel, 2013). The vector $X_{i t-1}$ comprises a parsimonious set of control variables such as bank size (measured by the logarithm of assets), annualized asset growth, loan book diversification and the ratios (over assets) of non-performing loans, equity, inter-bank lending, short-term borrowing and brokered deposits. We include as well two indicators on the ownership structure of banks, namely, a dummy for stand-alone banks and a dummy for banks that are owned by financial holding companies with nonbank subsidiaries. Finally, we include two variables from the financial statements of holding companies that capture more explicitly the possible impact of non-bank activities, carried out under the umbrella of the holding company, on a group's performance. In particular, we include equity invested in nonbank subsidiaries and balances due from non-bank subsidiaries as a ratio of the holding's unconsolidated total assets.

The regressions are estimated by means of a cross-sectional and a time-varying panel setting. The cross-sectional analysis, based on bank-specific averages over the period 2002-12, has the advantage that random variations in income shares and the diversification measure are likely to average out. This means that the results can be interpreted in terms of banks' long-term strategy (Stiroh and Rumble, 2006). The identification of the relationship between bank performance and business model comes in this case entirely through the variation across banks. The cross-sectional analysis does not, however, take into account the possibility that individual business strategies might have changed over time. Moreover, it has been argued that the cross-sectional approach may introduce an omitted variable bias related to time-invariant heterogeneities across banks, such as for example management skills (Campa and Kedia, 2002). To address this issue, we estimate in addition fixed-effects regressions using yearly averages of quarterly observations. We believe, however, that the cross-sectional analysis is superior to the fixed-effects approach in our setting, since the year-to-year variation within banks is less likely to capture a bank's long-term strategy (business model) and more likely subject to unexpected random shocks, which would weaken the link between expected and actual returns.

The econometric model is subject to a potential endogeneity problem. More specifically, the performance measures include net income in the nominator - which itself includes the different income sources used in the definition of the right-hand side variables on banks' business strategy. This could eventually introduce an estimation bias, although the direction is ambiguous (Stiroh and Rumble, 2006). For instance, while positive shocks to interest income would, ceteris paribus, reduce the 
non-traditional income share (by increasing the denominator) and increase profits, positive shocks to non-interest income would be associated with increases in the non-traditional income share (through the nominator) and higher bank profits. To address this problem, we examine whether the results are robust to the use of predetermined information. In the cross-sectional analysis, we therefore split the sample into two parts and use the first sub-sample to calculate banks' average non-traditional income share and degree of diversification, while we use the second sub-sample to calculate the performance measures. In the panel estimations, on the other hand, we include the regressors with a lag of one year.

The effect of diversification and non-traditional business orientation on bank performance can be assessed by the key coefficients $\beta_{1}, \beta_{1}{ }^{*}, \beta_{2}$, and $\beta_{2}{ }^{*}$. More specifically, the marginal effects are given by

$$
\frac{\partial y_{i t}}{\partial D I V_{i t-1}}=\beta_{1}+2 \beta_{1}^{*} D I V_{i t-1} \quad \text { and } \quad \frac{\partial y_{i t}}{\partial N T_{i t-1}}=\beta_{2}+2 \beta_{2}^{*} N T_{i t-1}
$$

For example, if we find that $\beta_{7}$ is significantly positive and $\beta_{1}{ }^{*}$ is not statistically different from zero, then there would be evidence of a positive and linear relationship between higher diversification and bank performance. Whether there is a non-linear relationship depends on the significance of the second coefficient $\beta_{1}{ }^{*}$. For instance, if we find that $\beta_{7}$ is significantly positive and that $\beta_{1}{ }^{*}$ is significantly negative, then the relationship between bank performance and diversification would be positive for low levels of diversification with a decreasing marginal effect. The overall effect would turn negative when the degree of diversification exceeds a critical threshold $\left(D I V_{i t-1}>\left|\beta_{1} / 2 \beta_{1}^{*}\right|\right)$.

The control variables in vector $X_{i t-1}$ account for bank-level determinants of returns and risks that are not captured by diversification and the non-traditional income share. Bank size is included to control for factors related to the scale of a bank's operations. While larger banks are more likely to benefit from economies of scale and geographic diversification, their risk choices could be distorted by toobig-fail considerations and implicit bailout guarantees (Cerasi and Daltung, 2000; De Nicolo, 2001; Farhi and Tirole, 2012). Asset growth, capital, loan book diversification, non-performing loans, shortterm borrowing and brokered deposits control for banks' risk profile. Other things being equal, we expect that faster growing banks with lower levels of capital, less diversified loan portfolios, and higher levels of non-performing loans, short-term borrowing and brokered deposits are pursuing riskier strategies than the other banks (Demirgüç-Kunt and Huizinga, 2010; Huang and Ratnovski, 2011; Cole and White, 2012; Hahm et al., 2013).

With respect to the control variables on the ownership structure and intra-group activities, it has been shown that stand-alone banks have been riskier than commercial banks that belonged to a bank holding company (Ashcraft, 2008). However, this might not be the case, if a bank holding company owns non-bank subsidiaries (Geyfman and Yeager, 2009). Finally, higher fractions of equity invested in non-bank subsidiaries and balances due from non-bank subsidiaries could be an indication of lower or higher risks and returns. On the one hand, a banking group that is active in several markets might benefit from gains related to diversification and the scale of activities. On the other, it could make a group vulnerable to distortions created by agency problems between the various divisions within the 
group (Jensen, 1986; Schmid and Walter, 2009). Summary statistics of the regression variables, expressed as averages over our sample period, are shown in Table $2 .^{12}$

The regression results of the cross-sectional approach, estimated for bank averages over the period 2002-12, are shown in Table 3. In specifications 1-3 the regression variables are bank-specific averages over the period 2002-12, while in specification 4 we use predetermined averages over the period 2002 -07 for the independent variables and averages over 2008-12 for the dependent variables. Apart from a few exceptions, the control variables in vector $X_{i}$ enter the regressions significantly with the expected signs. For example, other things being equal, faster growing banks and banks with higher ratios of non-performing loans, inter-bank activities and brokered deposits have recorded lower returns and higher risks compared to the other banks. While better capitalization has been associated with lower risks only, banks with better diversified loan books recorded significantly higher returns with no differences in terms of volatility. Finally, higher fractions of short-term borrowing have been associated with significantly lower returns.

With respect to the control variables on the ownership structure and exposures to financial holding companies, we find evidence that stand-alone banks have been significantly less profitable compared to the other banks, while we do not find any notable difference in terms of income volatility. Whether or not a bank belongs to a financial holding company with non-bank subsidiaries has no effect on the risk/return profile across banks, which could be related to the overlap with the definition of nontraditional banks (see Table 1 and the related discussion). Similarly, equity invested in non-bank subsidiaries does not significantly affect a banking group's returns and risks. However, higher balances due from non-bank subsidiaries are a sign of vulnerability, since such exposures have been associated with both lower returns and higher risks on the group level.

The relationship between banks' business orientation and the two performance measures is in many specifications significant. Based on specifications 3 and 4 of Table 3, we plot in Figure 4 the effects of income diversification and non-traditional income share on the return on equity and its volatility, assuming that the other variables in the regressions are equal to their respective means. Although the main results are qualitatively similar, we will focus our discussion on specification 4 in which the righthand side variables are predetermined with respect to the measures on bank performance, shown in panels (c) and (d).

A higher non-traditional income share has a negative and non-linear effect on bank profitability. For the average bank with a non-traditional income share of close to 5 percent, return on equity is reduced by -1.4 percent of equity relative to a return of 3.4 percent at banks with a non-traditional income share of zero (see panel (c)). At the very end of the distribution, the marginal effect would start turning

\footnotetext{
${ }^{12}$ We removed outliers and excluded: returns of more than 30 percent of equity (99.5th percentile) and less than 45 percent (0.5th percentile), annual asset growth of more than 100 percent (99th percentile is 115 percent) and less than -100 percent (the 1st percentile is -16 ), ROE volatility of more than 60 percent (99.5th percentile), negative non-traditional income shares (2nd percentile), and non-traditional income shares of more than 100 percent (the 99th percentile is 41).
} 
positive, i.e. at a non-traditional income share of 29 percent $\left(\left|\beta_{2} / 2 \beta_{2}{ }^{*}\right|=0.306 / 2 * 0.525=0.29\right)$, and return on equity would be back at 2 percent at a non-traditional income share of 53 percent, indicating that banks that are heavily concentrated on non-traditional activities might have a higher return than the average bank. The non-traditional income share has a strong effect on bank risk across the two specifications (see panels (a) and (c)). For the average bank, income volatility is by 1.2 percent of equity higher relative to a volatility of 6.6 percent observed at banks with a zero share of non-traditional income (see panel (c)). The effect is increasing and becomes as high as 9.4 percent for banks with a non-traditional income share of 14 percent $\left(95^{\text {th }}\right.$ percentile).

Figure 4: Estimated relationship of bank performance and business orientation ${ }^{13}$

(a) Non-traditional income, 2002-12

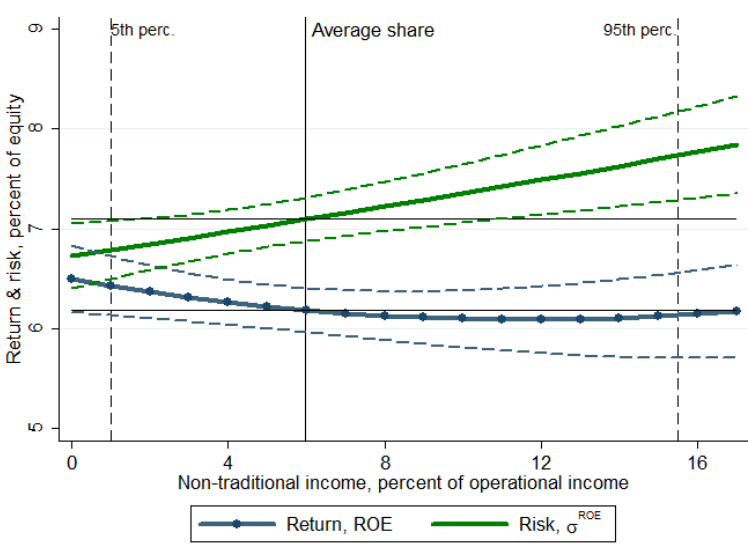

(c) Non-traditional income, 2008-12

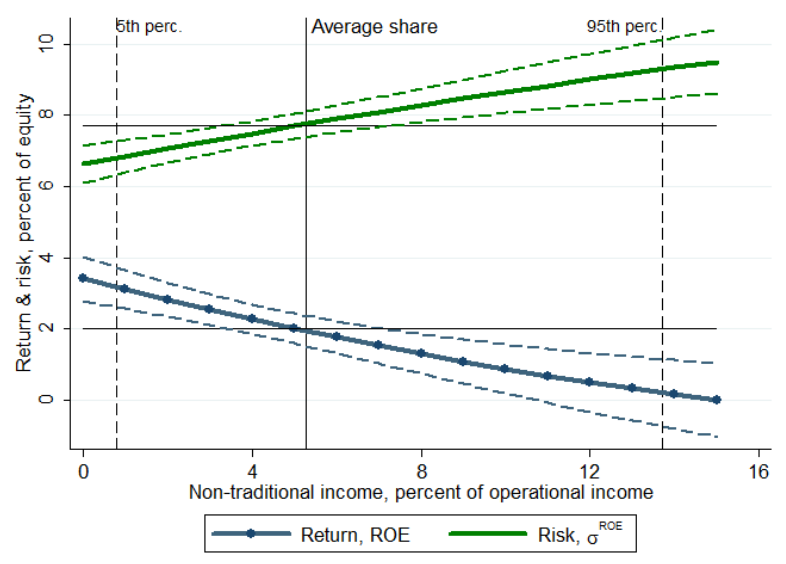

(b) Income diversification, 2002-12

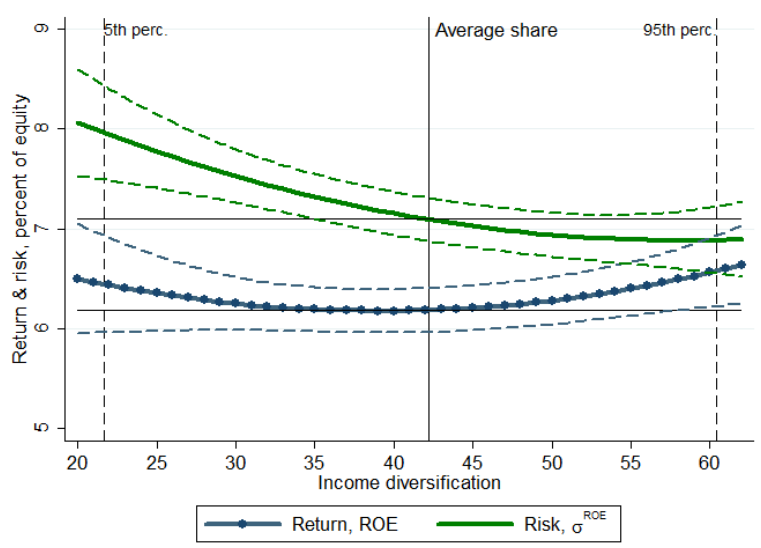

(d) Income diversification, 2008-12

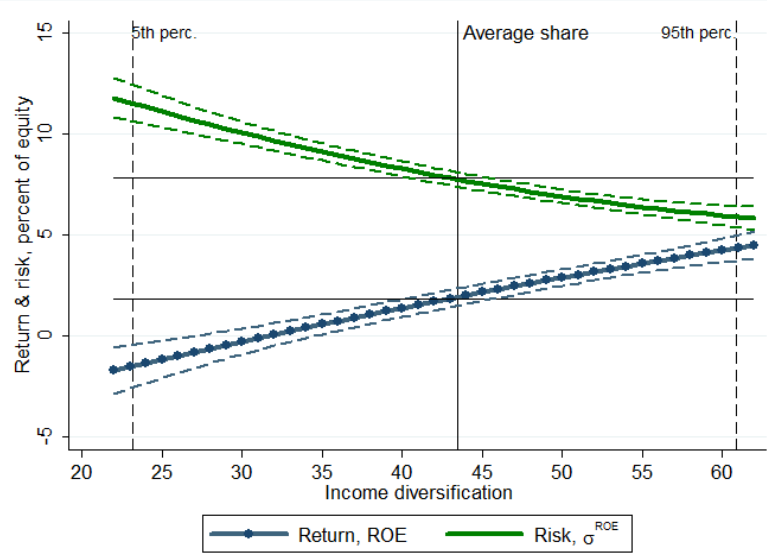

\footnotetext{
${ }^{13}$ The solid lines indicate the effect of non-traditional income and diversification on risks and returns. Panels (a) and (b) are based on specification 3 and (c) and (d) on specification 4 in Table 3. The dashed lines are confidence intervals for a significance level of 5 percent, calculated by the Delta Method. The vertical lines indicate different percentiles of the distribution of non-traditional income share and diversification.
} 
The risk/return implications of a higher degree of income diversification are quite different: while bank returns are positively affected, risks decrease significantly with a diminishing marginal effect. Relative to a bank with a very low degree of income diversification ( $5^{\text {th }}$ percentile), which has an income volatility of 11.6 percent of equity, the average bank with a diversification index of $0.43 * 100$ has a volatility of 7.8 percent (panel (d)). The volatility reaches 5.9 percent of equity at banks with a very high degree of diversification $\left(95^{\text {th }}\right.$ percentile), meaning that risks are reduced by close to one half relative to a bank with a very low level of diversification. The risk reduction benefits are accompanied by significant improvements in bank returns in specification 4 (panel (d)), while they are less important in specification 3 (panel (b)).

Next we discuss the results obtained from the fixed effects estimations shown in Table 4. This approach allows us to control for unobserved, time-invariant heterogeneity across banks and to investigate the risk/return implications of business orientation within banks. Technically this means that we replace the long-term averages over 2002-12 with yearly averages over four quarterly observations. The first specification in Table 4 shows for comparison the estimation results when using pooled OLS, while the second specification uses the fixed effects estimator. In the final specification, we interact the explanatory variables with a crisis dummy for 2007-09 to allow for possible changes in the relationships across normal times and periods of financial distress. As a precaution, we lag the regressors by one year to ensure that our results are not biased by potential endogeneity problems.

Generally, the results are qualitatively similar across the different estimators and specifications. After controlling for unobserved time-invariant differences across banks, which may reflect permanent differences in management skills or specialisation into particular industries, and other bank-specific determinants of returns and risks, we find - over the short-run - similar results to those obtained over the long-run in the regressions on bank risk: non-traditional activities, one year prior to the realization of profits, have been associated with significantly higher risks, while diversification has been associated with lower levels of risk. For instance, based on specification 2, income volatility of a bank with the average level of diversification ( $\mathrm{DIV}=0.42$ ) is by 0.4 percent of equity lower than the volatility of a bank with a very low level of income diversification (DIV=0.20), representing over one fifth of the average annual volatility of 1.9 percent. ${ }^{14}$ The marginal risk effect is decreasing, as implied by the positive and significant coefficient of the square of income diversification. The risk-minimizing level is reached at a Herfindahl index of $0.63\left(\left|\beta_{1} / 2 \beta_{1}^{*}\right|=0.033 /(2 * 0.026)=0.63\right)$, which means that - at the very end of the distribution of diversification - the risk reduction benefits become quantitatively less important. In the case of non-traditional activities, we find a weaker but non-linear risk augmenting effect compared to the cross-sectional analysis. To be more precise, the overall annual income volatility increases by 0.05 percent of equity at banks with a non-traditional income share of 10 percent relative to a purely traditional bank, but the effect becomes increasingly important, reaching for example 0.2 percent at a NT share of 20 percent and 0.8 percent at a NT share of 40 percent.

In terms of bank returns, we find that the results over the short-term differ from those obtained over the long-term. While income diversification is associated with a lower return on equity within banks,

\footnotetext{
${ }^{14}$ The difference is calculated as follows: $\beta_{1}{ }^{\star} D I V+\beta_{1}{ }^{*} D I V^{2}=-0.033^{*} D I V+0.026{ }^{\star} D I V^{2}$, with $D I V=0.42$ and 0.20 .
} 
non-traditional activities tend to increase bank profitability with a decreasing marginal effect. For instance, the return in year $t$ of the average bank with a non-traditional income share of 6 percent in year $\mathrm{t}-1$ is by 1.6 percent of equity higher compared to a bank that is fully concentrated on the traditional banking business. The return improvement represents close to one fifth of the average annual return on equity of 7.4 percent. In the case of diversification, we find a linear effect on bank returns which suggests, for example, that the return of the average bank ( $\mathrm{DIV}=0.42$ ) is by 1.7 percent lower over the short-term compared to the return of a bank with a very low level of diversification (DIV=0.20).

In summary, when comparing the results obtained by the cross-sectional and the fixed effects approach, we reach similar conclusions in terms of the risk assessment of banks' business strategy. Bank risks tended to decrease with higher income diversification and increase with higher nontraditional income shares. They differ, however, in the conclusion about the return implications. While there is evidence that returns decrease with non-traditional activities across banks, it appears that within banks - higher risks are partially compensated by higher returns. In the case of higher income diversification, we find that returns improve across banks, while within banks they seem to decrease. There are several potential explanations for these differences. As pointed out by Stiroh and Rumble (2006), an interpretation could be that only large differences in business strategies across banks, which only show up in the long-term, have an effect on returns (Campa and Kedia, 2002; Schoar, 2002). An alternative explanation might be related to the fact that yearly averages are only poor proxies of expected returns, risks and business strategies. This potential drawback applies particularly to the nontraditional income share, which tends to be low during crises for all banks, independent of their business orientation. Over the long run, on the other hand, such variations should average out, implying that the long-run average of the non-traditional income share is more likely to represent the targeted level.

\section{Robustness tests}

This section performs a number of sensitivity analyses with the objective to test whether our results are robust to different measures for bank risks, returns and business orientation. In a first step, we replace in the cross-sectional estimations which use predetermined averages on the right-hand side (specification 4 in Table 3), the return on equity with return on assets. The estimation results are shown in specifications 2 and 4 of Table 5. The effects of income diversification and non-traditional activities on the return on assets and its volatility are shown in Figure 5. It appears that our main conclusions are confirmed: non-traditional activities are associated with significantly lower returns and higher risks, while income diversification leads to risk reductions and increased returns.

In the second robustness test, we replace in the regressions the volatility of income with other measures of bank performance, namely, risk-adjusted profits - calculated by the ratio of the return on equity over its standard deviation - and the Z-Score defined by the ratio of the sum of the average return on assets and equity ratio over the standard deviation of the return on assets. The results shown in specifications 5 and 6 of Table 5 are consistent with our previous findings: income diversification is 
associated with higher financial stability (higher risk-adjusted profits and higher Z-Score), while nontraditional activities increase bank risks with a decreasing marginal effect in both cases.

Figure 5: Estimated relationship of bank performance (ROA) and business orientation ${ }^{15}$

(a) Non-traditional income, 2008-12

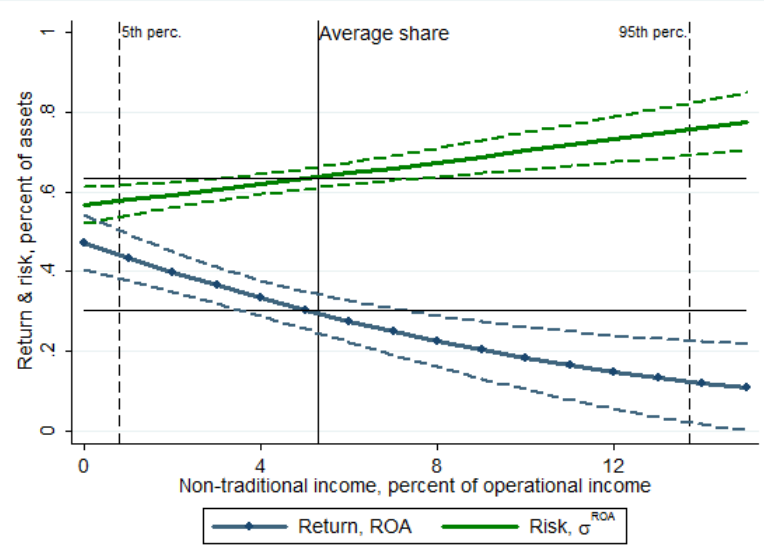

(b) Income diversification, 2008-12

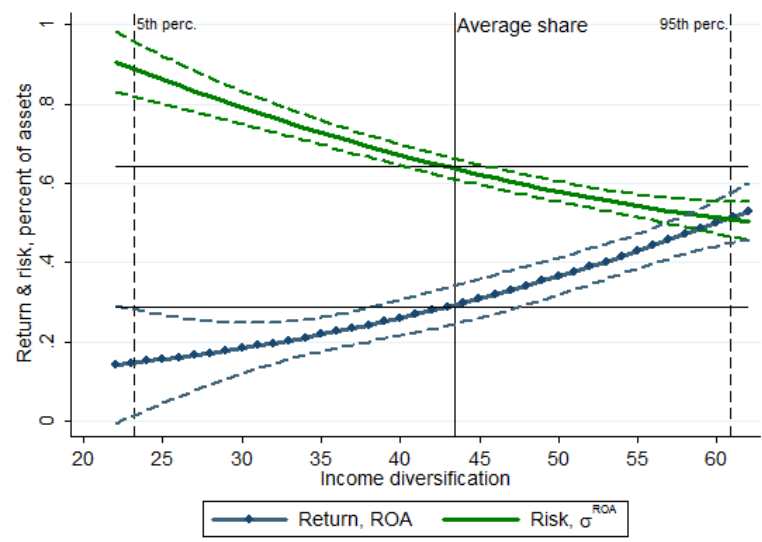

In the third sensitivity analysis, we decompose banks' non-traditional income share into its individual components to investigate in detail which activities in particular are driving the results. Table 6 shows for the cross-sectional specification - the estimation results for the different components of nontraditional income, which we calculated as ratios over operating income. Because the reporting requirements have become more detailed in 2007, we focus on the period 2007-12 and estimate two sets of regressions: (i) all variables are bank-specific averages over 2007-12; and (ii) the explanatory variables are averages over 2007, while the dependent variables are averages over 2008-12.

Specifications 1 and 2 show the estimation results when we replace the non-traditional income share by its 10 components. The results point to significant increases of returns in the case of insurance activities (underwriting and sale), net servicing fees ${ }^{16}$, net securitization income and the residual category "other non-interest income". There appear to be risk reduction benefits associated with feebased income from insurance underwriting, while overall risks increase with income generated by venture capital, net servicing fees and the category other non-interest income. The findings are broadly in line with previous studies on such a disaggregation (see Table 10 in DeYoung and Torna, 2014).

\footnotetext{
${ }^{15}$ The solid lines indicate the effect of non-traditional income and diversification on ROA and its standard deviation. The dashed lines are confidence intervals for a significance level of 5 percent, calculated by the Delta Method. The vertical lines indicate different percentiles of the distribution of the non-traditional income share and diversification.

${ }^{16}$ Servicing fees include income from servicing mortgages, credit cards and other financial assets held by other parties.
} 
Finally we decompose the residual category other non-interest income into its major components. This category, which has been overlooked in previous studies and which is difficult to interpret, represents an important part of non-interest income (see Figure 2) and is, as we have just shown, an important determinant of bank returns and risks. We identified the major components of this category by scanning the supplementary information on this variable by keywords and ended up with 25 broad categories. ${ }^{17}$ The corresponding estimation results are shown in specifications 3 and 4 of Table 6 , indicating that bank returns and risks are in many cases significantly affected by the sub-categories. The following items, for example, have significantly negative effects on bank returns, while increasing bank risks: electronic \& wire transfer fees, mortgage origination \& broker fees and legal fees \& settlements. Significant risk reductions have been associated with trust income $\&$ referral fees.

\section{The optimal mix of bank activities: A back-of-the-envelope calculation}

From a portfolio choice point of view, a bank can be interpreted as an agent who manages a portfolio of various types of assets which have different risk/return characteristics. Accordingly, a bank's optimal asset mix can be evaluated with the portfolio choice theory developed by Markowitz (1952). A difficulty that arises however is, that the risk/return characteristics of particular activities are hard to measure, because certain income-generating activities cannot be matched with the corresponding balance sheet positions, or the resources that have been employed into that activity. More specifically, while it is relatively straightforward to obtain information on the income earned from an activity (the nominator of the return), it is much more difficult to infer the invested amount (the denominator).

For most traditional banking activities, the actual return can be calculated directly from the income statement and balance sheet. For instance, the income statement provides information on the interest income generated by a bank's lending activity, while the stock of outstanding loans is reported in the balance sheet. Similarly, one can broadly match the interest income generated by investments into securities or trading assets with the corresponding balance sheet positions. The resources invested into Fee-for-Service activities, on the other hand, cannot be directly inferred from the financial accounts without further assumptions, as they involve in many cases contingent off-balance sheet positions or intangible assets, such as human capital or non-financial assets as information technology (Boyd and Gertler, 1994; Stiroh, 2006; Geyfman and Yeager, 2009). Nevertheless, we can roughly approximate the invested amount using a back-of-the-envelope approach.

More specifically, we consider 6 broad income generating activities: costumer lending, inter-bank lending, investments in securities \& trading assets, traditional non-interest activities (fiduciary and payment $\&$ deposit account services), insurance activities (underwriting and sale) and non-traditional non-interest activities (securities brokerage, investment banking, trading, servicing fees and

\footnotetext{
${ }^{17}$ Banks are required to specify in the appendix of the call reports, in a couple of words, the nature and amount of any other non-interest income that exceeds $\$ 25,000$ or 3 percent of other non-interest income. On average, the highest shares in other non-interest income have been observed for the categories that include the keywords debit card, merchant income, mortgage origination and broker fees, operating leases, intercompany administration fees and affiliate income.
} 
securitization). The returns on the interest-generating activities are calculated as follows: (i) for costumer lending we use the ratio of interest income on loans divided by total costumer loans; (ii) for inter-bank lending we use the ratio of interest income on federal funds sold over the balance sheet item federal funds sold; and (iii) for investments in securities and trading assets we use the ratio of the sum of interest and dividend income from securities and trading assets over the sum of securities (available-for-sale and held-to-maturity) and trading assets.

As for the calculation of the return on non-interest income generating activities, we have to impose further assumptions. Because fiduciary and payment $\&$ deposit account services tend to be offered to most of a bank's retail customers, who themselves also tend to be bank borrowers, we first calculate the ratio of income generated by these activities over the interest income generated by loans, and then we proxy the invested amount into these activities ("balance sheet equivalent") by the total of costumer loans multiplied by this ratio. Given that we use averages over 2010-12 across large and small banks, the short-term variations of this ratio should average out. A similar procedure is applied to insurance income, servicing fees and income related to securitization. As for the remaining categories (brokerage, trading and investment banking), we calculate the ratio of the income generated by each activity over the income generated by securities (for brokerage and investment banking) or over the income generated by trading assets (for trading), and then we proxy the balance sheet equivalent for these activities by the income ratios multiplied by securities and trading assets, respectively. The return on non-traditional non-interest income generating activities is then calculated by the sum of income from securities brokerage, investment banking, trading, servicing and securitization divided by the sum of balance sheet equivalents of these activities.

The procedure is applied to large and small banks separately, since large banks tend to be more involved in non-interest generating activities compared to small banks, and as such we expect that our proxies for the invested amounts vary according to bank size. The average returns and risks of each activity for the post-crisis period 2010-12 are represented across large and small banks in Figure 6. It appears that, consistently across large and small banks, the returns of the rather traditional activities (costumer lending, investments in securities \& trading assets and inter-bank lending) have been associated with the lowest volatility. For instance, the lending business generated in the considered period an average annual gross return of about 6 percent of total customer lending with a standard deviation between 2 and 3 percent. For both large and small banks, customer lending and traditional non-interest activities have been associated with the highest returns in the post-crisis period. Insurance activities and non-traditional activities have been associated with the highest volatility associated with a gross return in the range of 3 to 4 percent of their balance sheet equivalent. However, this does not necessarily imply that these activities should not be included in a bank's portfolio, rather this depends on the covariance terms.

Using the standard portfolio choice theory, we calculate the risk-minimizing mix of bank activities by minimizing the overall volatility of a bank's portfolio as follows:

$$
\min _{x} \frac{1}{2} x^{\prime} \Omega x, \quad \text { s.t. } \quad x^{\prime} 1=1 \text { and } x_{i} \geq 0
$$


where $\Omega$ is the variance-covariance matrix of the individual returns, $x_{i}$ the proportion invested in activity $i$, and $x_{i} \geq 0$ the no-short-selling constraint.

Figure 6: Average annual returns and risks by activity ${ }^{18}$

(a) Large banks

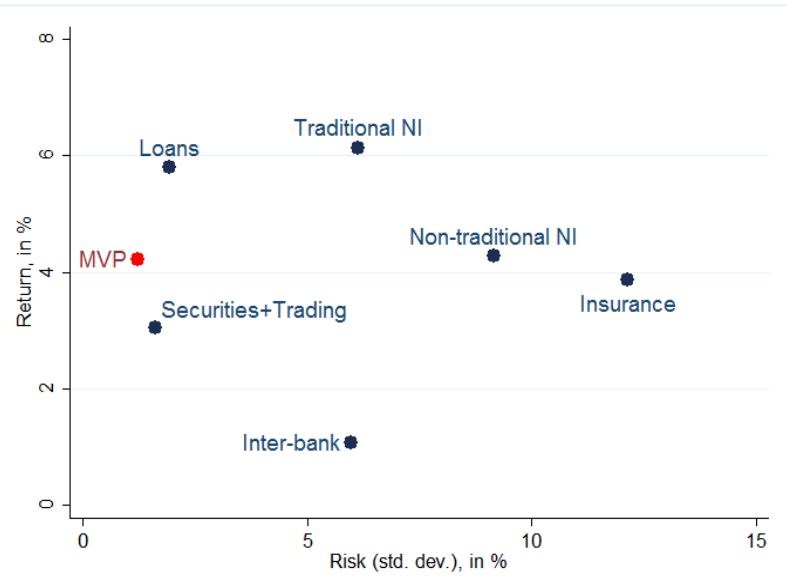

(b) Small banks

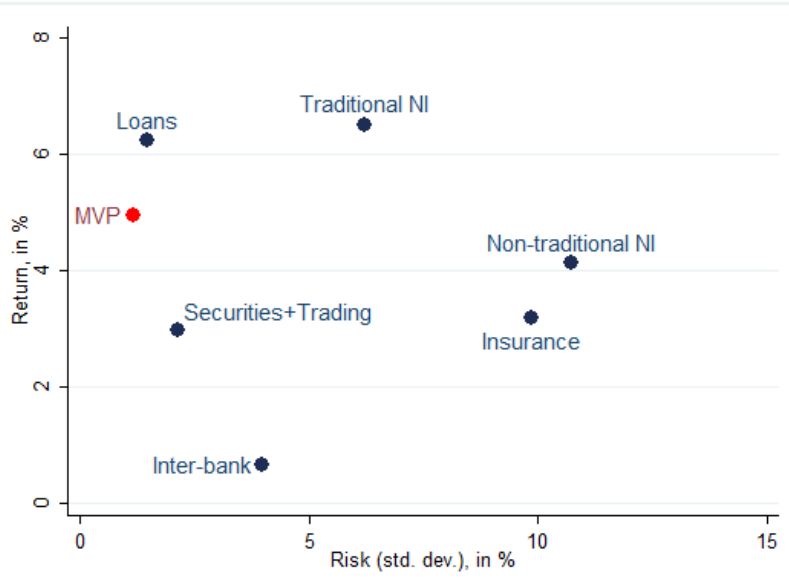

Table 7 reports the composition of the minimum variance portfolio (MVP) along with the highest and lowest correlations of the different activities. As can be seen in Figure 6, the minimum variance portfolio for large banks entails a return of close to 4 percent associated with a return volatility of 2 percent.

Table 7: The composition of the minimum variance portfolio

\begin{tabular}{l|lll}
\hline \hline & $\begin{array}{l}\text { Share in } \\
\text { MVP }\end{array}$ & Highest correlation & Lowest correlation \\
\hline Large banks & & & \\
Customer lending & 0.356 & Securities \& trading assets, 0.127 & Non-traditional activities, -0.041 \\
Securities \& trading assets & 0.534 & Customer lending, 0.127 & Traditional non-interest activities, -0.060 \\
Inter-bank lending & 0.038 & Customer lending, 0.041 & Traditional non-interest activities, -0.017 \\
Traditional non-interest activities & 0.048 & Non-traditional activities, 0.107 & Securities \& trading assets, -0.060 \\
Insurance & 0.005 & Traditional non-interest activities, 0.066 & Securities \& trading assets, -0.013 \\
Non-traditional activities & 0.018 & Traditional non-interest activities, 0.107 & Customer lending, -0.041 \\
\hline Small banks & & & \\
Customer lending & 0.609 & Traditional non-interest activities, 0.183 & Non-traditional activities, -0.037 \\
Securities \& trading assets & 0.278 & Customer lending, 0.027 & Insurance, -0.004 \\
Inter-bank lending & 0.084 & Non-traditional activities, 0.015 & Securities \& trading assets, -0.002 \\
Traditional non-interest activities & 0.008 & Customer lending, 0.183 & Non-traditional activities, -0.062 \\
Insurance & 0.007 & Traditional non-interest activities, 0.098 & Securities \& trading assets, -0.003 \\
Non-traditional activities & 0.015 & Inter-bank lending, 0.018 & Traditional non-interest activities, -0.062 \\
\hline \hline
\end{tabular}

\footnotetext{
18 The returns and risks are calculated as unweighted averages across large ( $>75^{\text {th }}$ percentile of assets) and small $\left(<75^{\text {th }}\right.$ percentile) banks over the period 2010-12. "MVP" denotes the minimum variance portfolio without short selling.
} 
For large banks, the minimum variance portfolio involves investing 36\% in customer lending, 53\% in securities \& trading assets, $4 \%$ in inter-bank lending, $5 \%$ in traditional non-interest generating activities, $0.5 \%$ in insurance activities and $2 \%$ in non-traditional activities. For small banks, the lowest risks are achieved when investing $61 \%$ in customer lending, $28 \%$ in securities \& trading assets, $8 \%$ in inter-bank lending, $1 \%$ in traditional non-interest activities, $0.5 \%$ in insurance and $1.5 \%$ in nontraditional activities. ${ }^{19}$

Our back-of-the-envelope calculation is, of course, subject to some potential drawbacks, but nevertheless, it allows us to sketch the risk/return trade-off faced by banks. First of all, it represents only an imperfect and recent snapshot of the risk/return characteristics of bank activities, but data limitations and the financial turmoil do not allow us to extend the analysis over a longer time horizon. ${ }^{20}$ And second, there is certainly some measurement error involved in our identification of the returns generated by fee-based income activities.

\footnotetext{
${ }^{19}$ It should be noted that the minimum variance portfolio might not be optimal from a social welfare perspective, where the risk characteristics of banks' portfolios are not the only objective. It can rather be seen as a benchmark against which other possible portfolios with higher returns and risks can be compared.

${ }^{20}$ The detailed reporting requirements used in this section are only available from 2007 onwards.
} 


\section{Concluding remarks}

We have examined the link between banks' income diversification, expansion into non-traditional activities and performance for the US banking system over the period 2002-12. Our cross-sectional results on the long-term suggest that non-traditional activities have been associated with higher return volatility and lower returns. This evidence is robust after controlling for a number of bank characteristics and the use of alternative performance measures. The decomposition of non-traditional activities into the individual components, however, reveals that not all non-traditional activities are risk augmenting. For instance, commercial banks' expansion into the underwriting of insurance has been associated with significant improvements in bank profits and volatilities. On the other hand, we find robust evidence that activity diversification across interest and non-interest generating activities has been associated with important risk reduction benefits and return improvements over the long-term. Our panel regression results on the short-term confirm our main findings on the risk implications. In other words, there are significant risk inducing effects of non-traditional activities and risk reducing effects of diversification. It appears, however, that banks' expansion into non-traditional activities has been associated with higher returns in the short-term, indicating that banks have been partially compensated for their increased riskiness. Taken together, the results suggest that there exists an optimal mix of activities in which banks should be allowed to operate.

Our findings are in line with previous studies that examined different periods and different samples of banks (Stiroh and Rumble, 2006; Geyfman and Yeager, 2009; DeYoung and Torna, 2013). They have important implications for regulatory authorities interested in the stability of banks, investors

interested in their performance, and bank clients who are concerned about the soundness of banking institutions and the stable provision of credits and payment services. The results on the long-term clearly cast doubt on the question of why commercial banks have been moving into particular nonnon-interest generating activities. One interpretation is that bank managers have overestimated the benefits of certain activities and underestimated the inherent risks. Alternatively, it could be that they have targeted short-term profits rather than the long-term implications of their decisions. 


\section{References}

Allen, L., Jagtiani, J. (2000), The risk effects of combining banking, securities and insurance activities, Journal of Economics and Business, 52

Avraham, D., Selvaggi, P., Vickery, J. (2012), A structural view of U.S. bank holding companies, FRBNY Economic Policy Review, 18

Ashcraft, A.B. (2008), Are bank holding companies a source of strength to their banking subsidiaries?, Journal of Money, Credit and Banking, 40

Bech, M., Keister, T. (2013), Liquidity regulation and the implementation of monetary policy, BIS Working Paper No 432

Bernanke, B. (2013), Stress testing banks: What have we learned?, Speech at the financial markets conference at the Federal Reserve Bank of Atlanta

Boot, A. (2011), Banking at the crossroads: How to deal with marketability and complexity?, Review of Development Finance, 1

Boot, A., Ratnovski, L. (2012), Banking and trading, IMF Working Paper, WP/12/238

Boyd, J.H., Gertler, M. (1994). Are banks dead? Or are the reports greatly exaggerated?, Federal Reserve Bank of Minneapolis Quarterly Review, 18

Brei, M., Gambacorta, L. (2014), The leverage ratio over the cycle, BIS Working Paper No 471

Breton, R., Clerc, L. (2015), Reforming the structures of the EU banking sector: Risks and challenges, Bankers, Markets \& Investors, 135

Campa, J.M., Kedia, S. (2002), Explaining the diversification discount, The Journal of Finance, 57

Calomiris, C.W. (1995), The Costs of Rejecting Universal Banking: American Finance in the German Mirror: 1870-1914, Chapter in "Coordination and Information: Historical Perspectives on the Organization of Enterprise", Editors: Lamoreaux and Raff

Calomiris, C.W. (2000), U.S. Bank deregulation in historical perspective, Cambridge University Press

Cerasi, V., Daltung, S. (2000), The optimal bank size of a bank, costs and benefits of diversification, European Economic Review, 44

Cole, R.A., White, L.J. (2012), Déjà vu all over again: The causes of U.S. commercial bank failures this time around, Journal of Financial Services Research, 42

Demirgüç-Kunt, A., Huizinga, H. (2010), Bank activity and funding strategies: The impact on risk and returns, Journal of Financial Economics, 98

Demsetz, R.S., Strahan, P.E. (1997), Diversification, size, and risk at bank holding companies, Journal of Money, Credit and Banking, 29

De Nicolo, G. (2001), Size, charter value and risk in banking: an international perspective, Proceedings Federal Reserve Bank of Chicago

DeYoung, R., Roland, K.P. (2001), Product mix and earnings volatility at commercial banks: Evidence from a degree of total leverage model, Journal of Financial Intermediation, 10

DeYoung, R., Rice, T. (2004), How do banks make money? The fallacies of fee income, Economic Perspectives, 28 
DeYoung, R., Torna, G. (2013), Nontraditional banking activities and bank failures during the financial crisis, Journal of Financial Intermediation, 22

Drucker, S., Puri, M. (2005), On the benefits of concurrent lending and underwriting, Journal of Finance, 60

Elsas, R., Hackethal, A., Holzhäuser, M. (2010), The anatomy of bank diversification. Journal of Banking \& Finance, 34

Farhi, E. and Tirole, J. (2012), Collective moral hazard, maturity mismatch and systemic bailouts, American Economic Review, 102

FSB - Financial Stability Board (2014), Structural banking reforms: Cross-border consistencies and global financial stability implications, Report to G20 Leaders for the November 2014 Summit

Furlong, F. (2000), The Gramm-Leach-Bliley Act and financial integration, FRBSF Economic Letter

Gambacorta, L., van Rixtel, A. (2013), Structural bank regulation initiatives: approaches and implications, Bancaria Editrice 6 and BIS Working Paper

Geyfman, V., and Yeager, T. J. (2009), On the riskiness of universal banking: Evidence from banks in the investment banking business pre-and post-GLBA. Journal of Money, Credit and Banking, 41

Hahm, J.H., Shin, H. S. and Shin, K. (2013), Noncore Bank Liabilities and Financial Vulnerability, Journal of Money, Credit and Banking, 45

Huang, R and Ratnovski, L. (2011), The dark side of bank wholesale funding, Journal of Financial Intermediation, 20

Jiménez, G. and Saurina, J. (2004), Collateral, type of lender and relationship banking as determinants of credit risk, Journal of Banking and Finance 28

Jensen, M.C. (1986), Agency costs of free cash flow, corporate finance and takeovers, American Economic Review, 76

Kahn, C. and Winton, A. (2004), Moral hazard and optimal subsidiary structure for financial institutions, The Journal of Finance, 59

Laeven, L. and Levine, R. (2007), Is there a diversification discount in financial conglomerates?, Journal of Financial Economics, 85

Lang, G. and Welzel, P. (1996), Efficiency and technical progress in banking: Empirical results from a panel of German cooperative banks, Journal of Banking and Finance, 20

Longford, N.T. (2010), Small-sample inference about variance and its transformations, SORT, 34

Markowitz, H. (1952), Portfolio selection, The Journal of Finance, 7

Merton, R.C. (1977), An analytic derivation of the cost of deposit insurance and loan guarantees, Journal of Banking and Finance, 1

Rime, B. and Stiroh, K. (2003), The performance of universal banks: Evidence from Switzerland, Journal of Banking and Finance, 27

Schmid, M.M., Walter, I. (2009), Do financial conglomerates create or destroy economic value?, Journal of Financial Intermediation, 18

Schoar, A. (2002), Effects of corporate diversification on productivity, The Journal of Finance, 57 
Stiroh, K.J., (2004), Diversification in banking: Is non-interest income the answer?, Journal of Money, Credit and Banking, 36

Stiroh, K.J., (2006), A portfolio view of banking with interest and non-interest assets, Journal of Money, Credit and Banking, 38

Stiroh, K.J., Rumble, A. (2006), The dark side of diversification: The case of US financial holding companies, Journal of Banking and Finance, 30

Valverde, S.C. and Fernandez, F.R. (2005), New evidence of scope economies among lending, deposittaking, loan commitments and mutual fund activities, Journal of Economics and Business, 57

Vander Vennet, R. (2002), Cost and profit efficiency of financial conglomerates and universal banks in Europe, Journal of Money, Credit and Banking, 34

Wall, L.D., Eisenbeis, R.A. (1984), Risk considerations in reregulating bank activities, Federal Reserve Bank of Atlanta, Economic Review, 69 
Table 1: Summary statistics across different types of banks, 2002-2012

\begin{tabular}{|c|c|c|c|c|c|c|c|c|c|c|c|c|c|c|}
\hline \multirow{2}{*}{$\begin{array}{l}\text { Panel A } \\
\text { Annualized income statement items, in percentage } \\
\text { of total assets }\end{array}$} & \multicolumn{2}{|c|}{ Non-traditional } & \multicolumn{2}{|c|}{ Traditional } & \multicolumn{2}{|c|}{ Universal/diversified } & \multicolumn{2}{|c|}{ Narrow/specialized } & \multicolumn{2}{|c|}{ FHC-owned } & \multicolumn{2}{|c|}{ Other banks } & \multicolumn{2}{|c|}{ All banks } \\
\hline & \multicolumn{2}{|c|}{$\begin{array}{c}\text { NT NII ratio higher than } \\
75^{\text {th }} \text { percentile }\end{array}$} & \multicolumn{2}{|c|}{$\begin{array}{l}\text { NT NII ratio lower } \\
\text { than } 25^{\text {th }} \text { percentile }\end{array}$} & \multicolumn{2}{|c|}{$\begin{array}{l}\text { Income } \mathrm{HHI} \text { higher } \\
\text { than } 75^{\text {th }} \text { percentile }\end{array}$} & \multicolumn{2}{|c|}{$\begin{array}{l}\text { Income } \mathrm{HHI} \text { ratio lower } \\
\text { than } 25^{\text {th }} \text { percentile }\end{array}$} & \multicolumn{2}{|c|}{$\begin{array}{l}\text { With non-bank } \\
\text { subsidiaries }\end{array}$} & \multicolumn{2}{|c|}{$\begin{array}{l}\text { Without non-bank } \\
\text { subsidiaries }\end{array}$} & \multicolumn{2}{|c|}{ 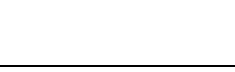 } \\
\hline Number of banks & & & \multirow{2}{*}{\multicolumn{2}{|c|}{$\begin{array}{c}1910 \\
245\end{array}$}} & \multicolumn{2}{|c|}{1910} & \multicolumn{2}{|c|}{1910} & \multicolumn{2}{|c|}{84} & \multicolumn{2}{|c|}{7555} & \multicolumn{2}{|c|}{7639} \\
\hline \multirow[t]{2}{*}{ Total assets at end-2007 (billions USD) } & \multicolumn{2}{|c|}{8,971} & & & & & & & 7 & & & & & \\
\hline & $2002-07$ & $2008-12$ & $2002-07$ & $2008-12$ & $2002-07$ & $2008-12$ & $2002-07$ & $2008-12$ & $2002-07$ & $2008-12$ & $2002-07$ & $2008-12$ & $2002-07$ & $2008-12$ \\
\hline Total interest income & 5.68 & 4.91 & 5.63 & 4.98 & 5.31 & 4.56 & 5.97 & 5.32 & 5.14 & 4.21 & 5.68 & 4.98 & 5.67 & 4.98 \\
\hline Interest on loans & 4.68 & 4.16 & 4.31 & 4.01 & 3.54 & 3.12 & 5.32 & 4.90 & 4.00 & 3.40 & 4.52 & 4.11 & 4.51 & 4.10 \\
\hline Loans secured by real estate & 3.12 & 2.99 & 2.69 & 2.69 & 2.10 & 2.00 & 3.67 & 3.58 & 2.53 & 2.20 & 2.92 & 2.86 & 2.92 & 2.85 \\
\hline Loans for agricultural production & 0.19 & 0.20 & 0.51 & 0.64 & 0.28 & 0.31 & 0.37 & 0.49 & 0.07 & 0.06 & 0.35 & 0.42 & 0.34 & 0.41 \\
\hline Commercial \& industrial loans & 0.80 & 0.63 & 0.66 & 0.57 & 0.58 & 0.47 & 0.88 & 0.73 & 0.72 & 0.53 & 0.73 & 0.60 & 0.73 & 0.60 \\
\hline Loans to individuals & 0.51 & 0.34 & 0.47 & 0.33 & 0.53 & 0.38 & 0.44 & 0.31 & 0.50 & 0.47 & 0.50 & 0.35 & 0.50 & 0.35 \\
\hline Interest \& dividend on securities & 0.77 & 0.63 & 1.03 & 0.82 & 1.50 & 1.26 & 0.40 & 0.31 & 0.89 & 0.67 & 0.93 & 0.75 & 0.93 & 0.75 \\
\hline Interest \& dividend on MBS & 0.25 & 0.27 & 0.24 & 0.27 & 0.45 & 0.48 & 0.10 & 0.12 & 0.45 & 0.39 & 0.25 & 0.27 & 0.25 & 0.27 \\
\hline Income from trading assets & 0.002 & 0.003 & 0.001 & 0.001 & 0.003 & 0.01 & 0.000 & 0.000 & 0.03 & 0.03 & 0.001 & 0.001 & 0.001 & 0.002 \\
\hline Income on federal funds sold & 0.13 & 0.04 & 0.18 & 0.06 & 0.13 & 0.05 & 0.17 & 0.04 & 0.08 & 0.03 & 0.14 & 0.04 & 0.14 & 0.04 \\
\hline Total interest expense & 1.96 & 1.49 & 2.07 & 1.65 & 1.75 & 1.27 & 2.23 & 1.83 & 1.97 & 1.28 & 1.99 & 1.56 & 1.99 & 1.55 \\
\hline Interest on deposits & 1.69 & 1.29 & 1.92 & 1.51 & 1.54 & 1.12 & 2.03 & 1.65 & 1.45 & 0.98 & 1.79 & 1.39 & 1.79 & 1.38 \\
\hline Interest on trading liabilities, borrowed money & 0.20 & 0.17 & 0.13 & 0.12 & 0.16 & 0.11 & 0.17 & 0.17 & 0.32 & 0.21 & 0.17 & 0.15 & 0.17 & 0.15 \\
\hline Provisions & 0.30 & 0.82 & 0.24 & 0.58 & 0.18 & 0.40 & 0.33 & 0.99 & 0.29 & 0.95 & 0.24 & 0.65 & 0.24 & 0.66 \\
\hline Non-interest income & 1.60 & 1.48 & 0.41 & 0.33 & 1.22 & 1.11 & 0.51 & 0.42 & 1.97 & 2.23 & 0.83 & 0.73 & 0.84 & 0.75 \\
\hline Fiduciary activities & 0.06 & 0.09 & 0.04 & 0.05 & 0.08 & 0.08 & 0.06 & 0.07 & 0.34 & 0.86 & 0.04 & 0.05 & 0.05 & 0.06 \\
\hline Service charges on deposit accounts & 0.41 & 0.34 & 0.28 & 0.23 & 0.51 & 0.42 & 0.21 & 0.18 & 0.39 & 0.30 & 0.36 & 0.30 & 0.36 & 0.30 \\
\hline Modern banking ${ }^{1}$ & 0.26 & 0.23 & 0.01 & 0.01 & 0.16 & 0.14 & 0.03 & 0.03 & 0.39 & 0.24 & 0.08 & 0.07 & 0.09 & 0.08 \\
\hline Insurance & 0.07 & 0.06 & 0.01 & 0.005 & 0.04 & 0.04 & 0.01 & 0.01 & 0.04 & 0.04 & 0.03 & 0.02 & 0.03 & 0.02 \\
\hline Other non-interest income & 0.61 & 0.54 & 0.08 & 0.09 & 0.39 & 0.37 & 0.16 & 0.18 & 0.77 & 0.75 & 0.26 & 0.26 & 0.27 & 0.27 \\
\hline Non-interest expense & 3.81 & 3.76 & 2.79 & 2.80 & 3.32 & 3.26 & 3.03 & 3.10 & 3.15 & 3.25 & 3.15 & 3.17 & 3.15 & 3.17 \\
\hline Salaries and employee benefits & 1.98 & 1.90 & 1.58 & 1.48 & 1.77 & 1.70 & 1.69 & 1.57 & 1.47 & 1.42 & 1.72 & 1.64 & 1.72 & 1.64 \\
\hline Expenses of premises and fixed assets & 0.49 & 0.46 & 0.37 & 0.35 & 0.43 & 0.40 & 0.41 & 0.40 & 0.42 & 0.37 & 0.42 & 0.40 & 0.42 & 0.40 \\
\hline Intangible asset losses & 0.02 & 0.06 & 0.01 & 0.02 & 0.02 & 0.03 & 0.01 & 0.04 & 0.05 & 0.19 & 0.01 & 0.03 & 0.01 & 0.04 \\
\hline Other non-interest expense & 1.32 & 1.35 & 0.83 & 0.94 & 1.10 & 1.12 & 0.92 & 1.09 & 1.21 & 1.27 & 0.99 & 1.09 & 0.99 & 1.09 \\
\hline Taxes and extra-ordinary adjustments & -0.31 & -0.12 & -0.20 & -0.06 & -0.24 & -0.12 & -0.24 & -0.04 & -0.53 & -0.39 & -0.24 & -0.08 & -0.25 & -0.06 \\
\hline Return on assets & 0.91 & 0.20 & 0.74 & 0.22 & 1.04 & 0.62 & 0.66 & -0.21 & 1.19 & 0.58 & 0.87 & 0.26 & 0.88 & 0.29 \\
\hline Return on equity & 9.59 & 0.94 & 7.55 & 1.19 & 9.73 & 5.12 & 7.80 & -3.50 & 12.68 & 2.88 & 8.96 & 1.56 & 9.00 & 1.97 \\
\hline
\end{tabular}

annuity sales, underwriting and sale of insurance, and net securitization income. 


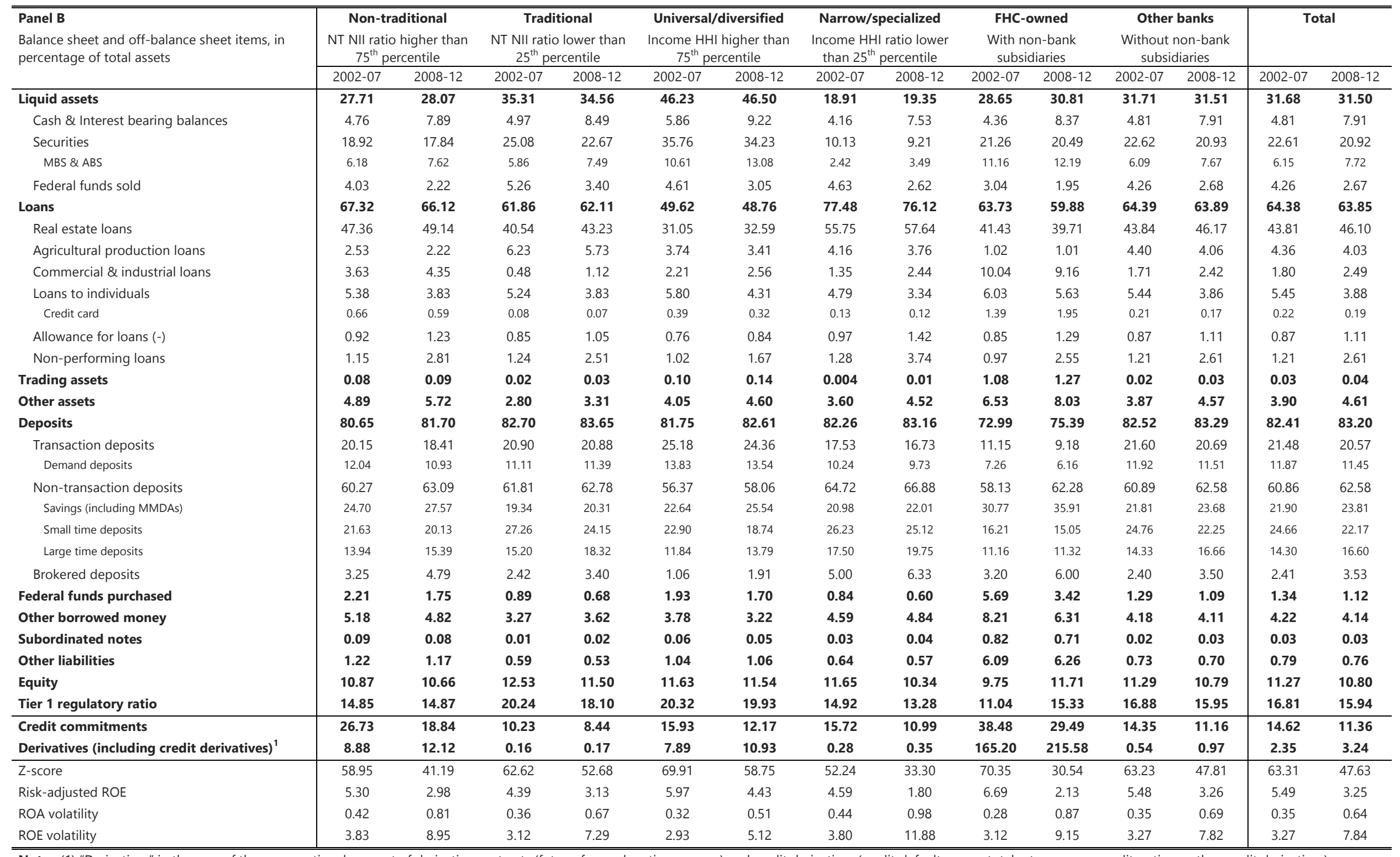

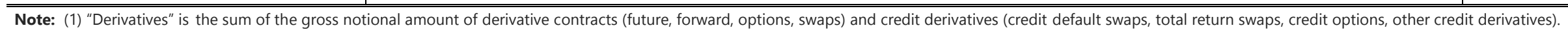


Table 2: Summary statistics of the regression variables: long-term averages

\begin{tabular}{|c|c|c|c|c|c|c|c|}
\hline Variable & Description & Obs. & Banks & Mean & Std. dev. & Min & Max \\
\hline ROE & Annualized net income over total equity, percent & 277,480 & 7639 & 0.062 & 0.089 & -0.449 & 0.291 \\
\hline ROE volatility & Standard deviation of ROE, percent & 277,480 & 7639 & 0.071 & 0.095 & 0.002 & 0.598 \\
\hline Income diversification & One minus the Herfindahl-Hirschmann Index of 13 income sources ${ }^{(1)}$, index & 277,480 & 7639 & 0.422 & 0.120 & 0.025 & 0.797 \\
\hline Income diversification, squared & Square of the income diversification index & 277,480 & 7639 & 0.193 & 0.100 & 0.001 & 0.635 \\
\hline Non-traditional income ratio & Non-traditional income over total operating income, percent & 277,480 & 7639 & 0.060 & 0.068 & 0.000 & 0.991 \\
\hline Non-traditional income, squared & Square of the non-traditional income ratio & 277,480 & 7639 & 0.008 & 0.037 & 0.000 & 0.982 \\
\hline Size & Natural logarithm of total assets (in millions USD & 277,480 & 7639 & 11.881 & 1.280 & 7.972 & 20.944 \\
\hline Asset growth & Annual growth rate of total assets, percent & 277,480 & 7639 & 0.091 & 0.101 & -0.403 & 0.828 \\
\hline Loan book diversification & One minus Loan Herfindahl-Hirschmann Index of 8 loan categories ${ }^{(2)}$, index & 277,480 & 7639 & 0.683 & 0.126 & 0.000 & 0.842 \\
\hline NPL ratio & Loans 30 days past due plus nonaccrual loans over total assets, percent & 277,480 & 7639 & 0.018 & 0.015 & 0.000 & 0.163 \\
\hline Tier 1 ratio & Tier 1 capital over total assets, percent & 277,480 & 7639 & 0.109 & 0.043 & 0.044 & 0.703 \\
\hline Inter-bank lending ratio & Federal fund sold over total assets, percent & 277,480 & 7639 & 0.034 & 0.037 & 0.000 & 0.601 \\
\hline Short-term funding ratio & Other borrowed money over total assets, percent & 277,480 & 7639 & 0.042 & 0.050 & 0.000 & 0.562 \\
\hline Brokered deposits ratio & Brokered deposits over total assets, percent & 277,480 & 7639 & 0.029 & 0.063 & 0.000 & 0.822 \\
\hline Dummy FHC with non-bank subsidiary & Dummy that equals to one if a FHC owns broker, dealer or insurance subsidiaries & 277,480 & 7639 & 0.011 & 0.104 & 0.000 & 1.000 \\
\hline Dummy stand-alone banks & Dummy that equals to one if the bank is not owned by a bank holding company & 277,480 & 7639 & 0.258 & 0.438 & 0.000 & 1.000 \\
\hline Equity invested in NB subsidiary & FHC's direct investments in non-bank subsidiaries over FHC unconsolidated assets, percent & 277,480 & 7639 & 0.007 & 0.036 & 0.000 & 0.883 \\
\hline Balance due to NB subsidiary & Balance due to non-bank subsidiaries over FHC unconsolidated assets, percent & 277,480 & 7639 & 0.047 & 0.100 & 0.000 & 0.619 \\
\hline
\end{tabular}

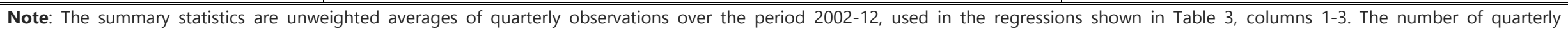

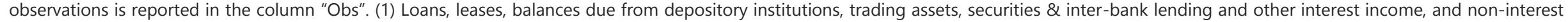

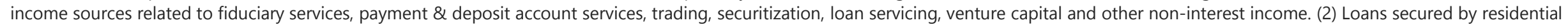

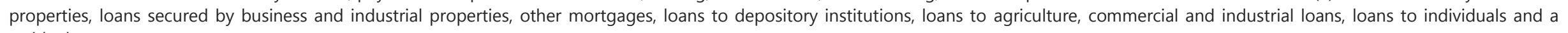
residual category. 
Table 3: Cross-sectional regression results

\begin{tabular}{|c|c|c|c|c|c|c|c|c|c|c|c|c|c|c|c|c|}
\hline \multirow{3}{*}{ Performance measure Y(i): } & \multicolumn{2}{|c|}{ Spec. 1} & \multicolumn{2}{|c|}{ Spec. 2} & \multicolumn{2}{|c|}{ Spec. 3} & \multicolumn{2}{|c|}{ Spec. 4} & \multicolumn{2}{|c|}{ Spec. 1} & \multicolumn{2}{|c|}{ Spec. 2} & \multicolumn{2}{|c|}{ Spec. 3} & \multicolumn{2}{|c|}{ Spec. 4} \\
\hline & \multicolumn{8}{|c|}{$Y(i)=\operatorname{ROE}(\mathbf{i})$} & \multicolumn{8}{|c|}{$Y(i)=$ volatility of $\operatorname{ROE}(i)$} \\
\hline & Coeff. & $\begin{array}{l}\text { Std. } \\
\text { dev. }\end{array}$ & Coeff. & $\begin{array}{l}\text { Std. } \\
\text { dev. }\end{array}$ & Coeff. & $\begin{array}{l}\text { Std. } \\
\text { dev. }\end{array}$ & Coeff. & $\begin{array}{l}\text { Std. } \\
\text { dev. }\end{array}$ & Coeff. & $\begin{array}{l}\text { Std. } \\
\text { dev. }\end{array}$ & Coeff. & $\begin{array}{l}\text { Std. } \\
\text { dev. }\end{array}$ & Coeff. & $\begin{array}{l}\text { Std. } \\
\text { dev. }\end{array}$ & Coeff. & $\begin{array}{l}\text { Std. } \\
\text { dev. }\end{array}$ \\
\hline Income diversification & -0.071 & 0.048 & & & -0.069 & 0.048 & $0.220^{* *}$ & 0.111 & $-0.080^{*}$ & 0.048 & & & $-0.094^{*}$ & 0.048 & $-0.325^{* \star *}$ & 0.093 \\
\hline Income diversification, squared & $0.094^{*}$ & 0.054 & & & 0.088 & 0.054 & -0.077 & 0.122 & 0.080 & 0.054 & & & 0.080 & 0.054 & $0.210^{\star \star}$ & 0.102 \\
\hline Non-traditional income & & & $-0.067^{\star *}$ & 0.030 & $-0.070^{* *}$ & 0.031 & $-0.306^{* * *}$ & 0.073 & & & 0.027 & 0.030 & $0.059^{*}$ & 0.032 & $0.225^{* * *}$ & 0.062 \\
\hline Non-traditional income, squared & & & $0.298^{* * *}$ & 0.058 & $0.300^{* * *}$ & 0.059 & $0.525^{* * \star}$ & 0.143 & & & 0.076 & 0.057 & 0.039 & 0.058 & $-0.221^{* *}$ & 0.109 \\
\hline Size & $0.007^{* * *}$ & 0.001 & $0.007^{* * *}$ & 0.001 & $0.006^{* * *}$ & 0.001 & $-0.005^{* *}$ & 0.002 & -0.000 & 0.001 & -0.001 & 0.001 & -0.001 & 0.001 & $0.006^{* * *}$ & 0.002 \\
\hline Asset growth & $-0.147^{* * *}$ & 0.012 & $-0.143^{* * *}$ & 0.011 & $-0.142^{* * *}$ & 0.012 & $-0.270^{* * *}$ & 0.021 & $0.114^{* * *}$ & 0.012 & $0.123^{* * *}$ & 0.011 & $0.111^{* * *}$ & 0.012 & $0.209^{* * *}$ & 0.018 \\
\hline Loan book diversification & $0.027^{\star \star \star}$ & 0.008 & $0.037^{\star \star \star}$ & 0.008 & $0.037^{\star \star \star}$ & 0.008 & $0.069^{\star \star \star}$ & 0.015 & -0.003 & 0.007 & -0.0003 & 0.007 & 0.004 & 0.007 & -0.001 & 0.011 \\
\hline NPL ratio & $-2.695^{* \star *}$ & 0.108 & $-2.700^{* * *}$ & 0.104 & $-2.689^{* * *}$ & 0.109 & $-1.374^{* * *}$ & 0.233 & $3.138^{* * *}$ & 0.120 & $3.174^{* \star *}$ & 0.116 & $3.115^{* * *}$ & 0.121 & $0.965^{* * *}$ & 0.170 \\
\hline Tier 1 ratio & $-0.251^{\star \star \star}$ & 0.034 & $-0.289^{* * *}$ & 0.034 & $-0.292^{* * *}$ & 0.034 & -0.038 & 0.049 & $-0.203^{* * *}$ & 0.028 & $-0.223^{* * *}$ & 0.028 & $-0.218^{* \star *}$ & 0.027 & $-0.116^{* \star *}$ & 0.038 \\
\hline Inter-bank lending ratio & $-0.116^{* \star *}$ & 0.027 & $-0.139^{* * *}$ & 0.025 & $-0.143^{* * *}$ & 0.025 & $-0.221^{* * *}$ & 0.043 & $0.216^{* * *}$ & 0.027 & $0.199^{* * *}$ & 0.026 & $0.199^{* * *}$ & 0.026 & $0.126^{* * *}$ & 0.034 \\
\hline Short-term funding ratio & $-0.084^{* * *}$ & 0.020 & $-0.091^{* * *}$ & 0.020 & $-0.089^{* * *}$ & 0.020 & $-0.088^{* *}$ & 0.038 & $0.066^{* * *}$ & 0.021 & $0.063^{* * *}$ & 0.021 & $0.061^{* * *}$ & 0.021 & 0.048 & 0.031 \\
\hline Brokered deposits ratio & -0.044 & 0.027 & $-0.051^{*}$ & 0.027 & $-0.053^{*}$ & 0.028 & $-0.187^{* * *}$ & 0.060 & $0.180^{* * *}$ & 0.024 & $0.179^{* * *}$ & 0.024 & $0.168^{* * *}$ & 0.025 & $0.229^{* * *}$ & 0.050 \\
\hline Dummy FHC with non-bank subs. & $-0.014^{* *}$ & 0.007 & $-0.015^{* *}$ & 0.007 & $-0.017^{* *}$ & 0.007 & 0.017 & 0.015 & -0.001 & 0.009 & -0.004 & 0.009 & -0.004 & 0.009 & -0.013 & 0.017 \\
\hline Dummy stand-alone banks & $-0.022^{\star \star \star}$ & 0.002 & $-0.022^{\star \star *}$ & 0.002 & $-0.022^{* \star *}$ & 0.002 & $-0.009^{\star *}$ & 0.005 & $0.004^{*}$ & 0.002 & $0.005^{* *}$ & 0.002 & $0.005^{* *}$ & 0.002 & -0.004 & 0.004 \\
\hline Equity invested in NB subsidiaries & 0.013 & 0.032 & 0.019 & 0.033 & 0.017 & 0.032 & 0.004 & 0.068 & -0.013 & 0.026 & -0.011 & 0.026 & -0.012 & 0.025 & -0.039 & 0.042 \\
\hline Balance due to NB subsidiaries & $-0.055^{\star \star \star}$ & 0.011 & $-0.058^{* \star *}$ & 0.011 & $-0.057^{\star \star \star}$ & 0.011 & $-0.127^{\star \star \star}$ & 0.024 & $0.157^{* * *}$ & 0.013 & $0.155^{* * *}$ & 0.013 & $0.153^{* * *}$ & 0.013 & $0.118^{* * *}$ & 0.021 \\
\hline Constant & $0.080^{* * *}$ & 0.017 & $0.069^{* * *}$ & 0.014 & $0.082^{* * *}$ & 0.018 & 0.033 & 0.037 & $0.031^{\star}$ & 0.017 & 0.020 & 0.013 & $0.039^{* *}$ & 0.017 & $0.063^{* *}$ & 0.029 \\
\hline Observations & 7639 & & 7639 & & 7639 & & 6024 & & 7639 & & 7639 & & 7639 & & 6024 & \\
\hline R-squared, adjusted & 0.300 & & 0.305 & & 0.306 & & 0.174 & & 0.352 & & 0.354 & & 0.355 & & 0.168 & \\
\hline
\end{tabular}

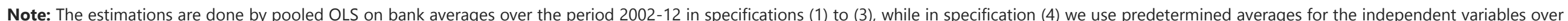
2002-07, and for the dependent variables we use averages over 2008-12. Robust standard errors are reported. $(* * *, * *, *)$ indicate significance on the 1,5 and 10 percent levels. 
Table 4: Panel regression results

\begin{tabular}{|c|c|c|c|c|c|c|c|c|c|c|c|c|c|c|}
\hline \multirow{4}{*}{$\begin{array}{l}\text { Performance measure } \\
Y(\text { it): }\end{array}$} & \multirow{2}{*}{\multicolumn{2}{|c|}{ Spec. 1}} & \multirow{2}{*}{\multicolumn{2}{|c|}{$\begin{array}{c}\text { Spec. } 2 \\
\mathbf{Y ( i t ) = R O E ( i t )}\end{array}$}} & \multirow{2}{*}{\multicolumn{2}{|c|}{ Spec. 3}} & \multirow{2}{*}{\multicolumn{2}{|c|}{ Spec. 1}} & \multicolumn{2}{|c|}{ Spec. 2} & \multicolumn{2}{|c|}{ Spec. $2^{*}$} & \multicolumn{2}{|l|}{ Spec. 3} \\
\hline & & & & & & & & & $Y(i t)$ & volati & $y$ of ROE & & & \\
\hline & \multicolumn{2}{|c|}{ Pooled OLS } & \multicolumn{2}{|c|}{ Fixed effects } & \multicolumn{2}{|c|}{ Fixed effects } & \multicolumn{2}{|c|}{ Pooled OLS } & \multicolumn{2}{|c|}{ Fixed effects } & \multicolumn{2}{|c|}{ Fixed effects } & \multicolumn{2}{|c|}{ Fixed effects } \\
\hline & Coeff. & $\begin{array}{l}\text { Std. } \\
\text { dev. }\end{array}$ & Coeff. & $\begin{array}{l}\text { Std. } \\
\text { dev. }\end{array}$ & Coeff. & $\begin{array}{l}\text { Std. } \\
\text { dev. }\end{array}$ & Coeff. & $\begin{array}{l}\text { Std. } \\
\text { dev. }\end{array}$ & Coeff. & $\begin{array}{l}\text { Std. } \\
\text { dev. }\end{array}$ & Coeff. & $\begin{array}{l}\text { Std. } \\
\text { dev. }\end{array}$ & Coeff. & $\begin{array}{l}\text { Std. } \\
\text { dev. }\end{array}$ \\
\hline Income diversification & $-0.040^{*}$ & 0.021 & $-0.076^{*}$ & 0.040 & $-0.094^{* *}$ & 0.040 & $-0.050^{* * *}$ & 0.006 & $-0.033^{* *}$ & 0.013 & $-0.025^{* *}$ & 0.010 & $-0.034^{* * t *}$ & 0.013 \\
\hline Income diversification ${ }^{*} \mathrm{C}$ & & & & & 0.005 & 0.043 & & & & & & & -0.001 & 0.016 \\
\hline Income div., squared & 0.008 & 0.024 & 0.016 & 0.046 & 0.020 & 0.046 & $0.051^{* * *}$ & 0.007 & $0.026^{*}$ & 0.016 & $0.020^{*}$ & 0.012 & $0.032^{* *}$ & 0.015 \\
\hline Income div., squared ${ }^{\star} \mathrm{C}$ & & & & & 0.052 & 0.049 & & & & & & & -0.007 & 0.018 \\
\hline Non-traditional income & $0.066^{* * *}$ & 0.015 & $0.275^{* * *}$ & 0.039 & $0.236^{* * *}$ & 0.039 & 0.008 & 0.005 & -0.012 & 0.012 & -0.009 & 0.009 & -0.006 & 0.012 \\
\hline Non-traditional income ${ }^{*} \mathrm{C}$ & & & & & 0.045 & 0.032 & & & & & & & -0.004 & 0.013 \\
\hline NT income, squared & $0.096^{* * *}$ & 0.028 & $-0.211^{* *}$ & 0.087 & $-0.161^{*}$ & 0.088 & $0.041^{* * *}$ & 0.009 & $0.049^{*}$ & 0.026 & $0.037^{*}$ & 0.020 & $0.047^{*}$ & 0.027 \\
\hline NT income, squared ${ }^{*} \mathrm{C}$ & & & & & $-0.134^{* *}$ & 0.053 & & & & & & & 0.001 & 0.023 \\
\hline Size & $0.005^{* * *}$ & 0.000 & $0.018^{* * *}$ & 0.004 & $0.030^{* * *+}$ & 0.004 & $-0.001^{* * *}$ & 0.0001 & $0.002^{*}$ & 0.001 & $0.002^{*}$ & 0.001 & -0.001 & 0.001 \\
\hline Asset growth & $-0.026^{* * *+}$ & 0.004 & $0.038^{* * *}$ & 0.005 & $0.047^{* * *}$ & 0.006 & $0.005^{* * *}$ & 0.001 & $-0.009^{* * *}$ & 0.002 & $-0.007^{* * *}$ & 0.001 & $-0.011^{* * *}$ & 0.002 \\
\hline Loan diversification & $0.082^{* * *}$ & 0.003 & $-0.039^{* *}$ & 0.019 & -0.020 & 0.017 & 0.001 & 0.001 & 0.001 & 0.005 & 0.001 & 0.004 & -0.004 & 0.005 \\
\hline NPL ratio & $-2.217^{* * *}$ & 0.059 & $-2.587^{* * *}$ & 0.092 & $-2.187^{* * *}$ & 0.090 & $0.587^{* * *}$ & 0.016 & $0.593^{* * *}$ & 0.025 & $0.451^{* * *}$ & 0.019 & $0.526^{* * *}$ & 0.027 \\
\hline Tier 1 ratio & $-0.183^{* * *}$ & 0.014 & $-0.206^{* * *}$ & 0.045 & $-0.191^{* * *}$ & 0.046 & $-0.081^{* * *}$ & 0.004 & $-0.062^{* * *}$ & 0.013 & $-0.046^{* * *}$ & 0.010 & $-0.071^{* * *}$ & 0.013 \\
\hline Inter-bank lending ratio & $-0.138^{* * t}$ & 0.011 & $-0.054^{* * *}$ & 0.017 & -0.021 & 0.018 & $0.029^{* * *}$ & 0.003 & 0.007 & 0.006 & 0.005 & 0.004 & 0.003 & 0.006 \\
\hline Short-term funding ratio & $-0.083^{* * * *}$ & 0.008 & $-0.120^{* * *}$ & 0.020 & $-0.086^{* * *}$ & 0.020 & $0.019^{* * *}$ & 0.003 & $0.030^{* * *}$ & 0.008 & $0.024^{* * *}$ & 0.006 & 0.010 & 0.008 \\
\hline Brokered deposits ratio & $-0.073^{* * * *}$ & 0.012 & $-0.166^{* * *}$ & 0.024 & $-0.054^{* *}$ & 0.023 & $0.043^{* * *}$ & 0.003 & $0.049^{* * *}$ & 0.008 & $0.038^{* * *}$ & 0.006 & $0.028^{* * *}$ & 0.008 \\
\hline FHC with NB subs. & $-0.016^{* * *}$ & 0.004 & 0.028 & 0.031 & 0.021 & 0.027 & 0.001 & 0.002 & -0.022 & 0.013 & -0.017 & 0.010 & -0.021 & 0.013 \\
\hline Equity invested in NB subs & $-0.038^{* *}$ & 0.017 & -0.039 & 0.031 & -0.041 & 0.030 & $0.007^{*}$ & 0.004 & $0.026^{* *}$ & 0.011 & $0.020^{* *}$ & 0.008 & $0.027^{* *}$ & 0.011 \\
\hline Balances due from NB subs & $-0.059^{* * *}$ & 0.006 & $-0.089^{* * *}$ & 0.013 & $-0.074^{* * *}$ & 0.013 & $0.023^{* * *}$ & 0.002 & $0.022^{* * *}$ & 0.004 & $0.017^{\star \star \star *}$ & 0.003 & $0.017^{* * *}$ & 0.004 \\
\hline Size $^{*} \mathrm{C}$ & & & & & $-0.008^{* * *}$ & 0.001 & & & & & & & $0.003^{* * *}$ & 0.000 \\
\hline Asset growth ${ }^{\star} \mathrm{C}$ & & & & & $-0.030^{* * * *}$ & 0.009 & & & & & & & $0.009^{* * *}$ & 0.003 \\
\hline Loan diversification ${ }^{*} \mathrm{C}$ & & & & & $-0.014^{* *}$ & 0.007 & & & & & & & 0.004 & 0.003 \\
\hline NPL ratio*C & & & & & $-1.082^{* * *}$ & 0.102 & & & & & & & $0.175^{* * *}$ & 0.033 \\
\hline Tier 1 ratio*C & & & & & $0.075^{* * * *}$ & 0.027 & & & & & & & -0.005 & 0.009 \\
\hline Inter-bank lending ratio* $\mathrm{C}$ & & & & & $-0.122^{* * *}$ & 0.020 & & & & & & & $0.018^{* *}$ & 0.007 \\
\hline Short-term funding ratio* $\mathrm{C}$ & & & & & $-0.033^{*}$ & 0.018 & & & & & & & $0.039^{* * *}$ & 0.008 \\
\hline Brokered deposits ratio ${ }^{*} \mathrm{C}$ & & & & & $-0.151^{* * *}$ & 0.022 & & & & & & & $0.023^{* * *}$ & 0.007 \\
\hline FHC with NB subs. ${ }^{*} \mathrm{C}$ & & & & & $-0.017^{*}$ & 0.010 & & & & & & & $0.007^{\star}$ & 0.004 \\
\hline Equity inv. in NB subs. ${ }^{*} \mathrm{C}$ & & & & & 0.022 & 0.039 & & & & & & & -0.008 & 0.014 \\
\hline Balance due NB subs. ${ }^{*} \mathrm{C}$ & & & & & $-0.047^{* * * x}$ & 0.012 & & & & & & & $0.013^{* * *}$ & 0.005 \\
\hline Constant & $0.066^{* * *}$ & 0.008 & 0.002 & 0.052 & $-0.160^{* * * *}$ & 0.050 & $0.030^{* * *}$ & 0.002 & -0.008 & 0.017 & -0.007 & 0.013 & $0.036^{* *}$ & 0.016 \\
\hline Observations & 52534 & & 52534 & & 52534 & & 52534 & & 52534 & & 52534 & & 52534 & \\
\hline Number of banks & 6500 & & 6500 & & 6500 & & 6500 & & 6500 & & 6500 & & 6500 & \\
\hline $\mathrm{R} 2$, within & & & 0.346 & & 0.377 & & & & 0.167 & & 0.166 & & 0.180 & \\
\hline R2, between & & & 0.106 & & 0.101 & & & & 0.201 & & 0.200 & & 0.234 & \\
\hline R2, overall & 0.253 & & 0.199 & & 0.198 & & 0.193 & & 0.173 & & 0.171 & & 0.196 & \\
\hline
\end{tabular}

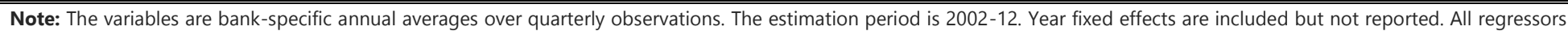

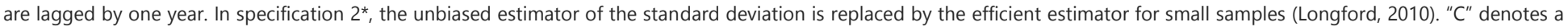

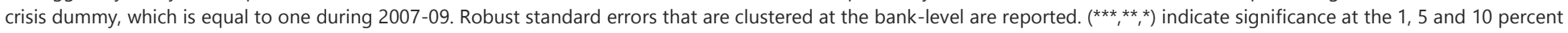
levels. 
Table 5: Cross-sectional regression results, robustness tests

\begin{tabular}{|c|c|c|c|c|c|c|c|c|c|c|c|c|}
\hline \multirow[t]{2}{*}{ Performance measure Y(i): } & \multicolumn{2}{|c|}{$\begin{array}{l}\text { Spec. } 1 \\
\text { ROE(i) }\end{array}$} & \multicolumn{2}{|c|}{$\begin{array}{l}\text { Spec. } 2 \\
\text { ROA(i) }\end{array}$} & \multicolumn{2}{|c|}{$\begin{array}{c}\text { Spec. } 1 \\
\text { Volatility of } \\
\text { ROE(i) }\end{array}$} & \multicolumn{2}{|c|}{$\begin{array}{c}\text { Spec. } 2 \\
\text { Volatility of } \\
\text { ROA(i) }\end{array}$} & \multicolumn{2}{|c|}{$\begin{array}{c}\text { Spec. } 3 \\
\text { Risk-adjusted } \\
\text { ROE(i) }\end{array}$} & \multicolumn{2}{|c|}{$\begin{array}{c}\text { Spec. } 4 \\
\text { Z-score(i) }\end{array}$} \\
\hline & Coeff. & $\begin{array}{l}\text { Std. } \\
\text { Dev. }\end{array}$ & Coeff. & $\begin{array}{l}\text { Std. } \\
\text { Dev. }\end{array}$ & Coeff. & $\begin{array}{l}\text { Std. } \\
\text { Dev. }\end{array}$ & Coeff. & $\begin{array}{l}\text { Std. } \\
\text { Dev. }\end{array}$ & Coeff. & $\begin{array}{l}\text { Std. } \\
\text { Dev. }\end{array}$ & Coeff. & $\begin{array}{l}\text { Std. } \\
\text { Dev. }\end{array}$ \\
\hline Income diversification & $0.220^{* *}$ & 0.111 & -0.002 & 0.017 & $-0.325^{* * *}$ & 0.093 & $-0.021^{* * *}$ & 0.007 & -0.009 & 0.022 & $0.577^{* *}$ & 0.235 \\
\hline Income diversification, squared & -0.077 & 0.122 & 0.014 & 0.018 & $0.210^{* *}$ & 0.102 & $0.014^{*}$ & 0.008 & $0.047^{\star}$ & 0.026 & -0.179 & 0.278 \\
\hline Non-traditional income & $-0.306^{\star \star *}$ & 0.073 & $-0.039^{* \star *}$ & 0.009 & $0.225^{* * *}$ & 0.062 & $0.013^{* *}$ & 0.006 & $-0.110^{* \star *}$ & 0.014 & $-1.023^{\star \star \star}$ & 0.166 \\
\hline Non-traditional income, squared & $0.525^{* * *}$ & 0.143 & $0.097^{* * *}$ & 0.025 & $-0.221^{* *}$ & 0.109 & 0.007 & 0.012 & $0.159^{* * *}$ & 0.023 & $0.873^{\star * *}$ & 0.250 \\
\hline Size & $-0.005^{\star \star}$ & 0.002 & -0.0002 & 0.0002 & $0.006^{\star \star \star}$ & 0.002 & $0.001^{\star \star *}$ & 0.0001 & $0.001^{*}$ & 0.0005 & 0.007 & 0.005 \\
\hline Asset growth & $-0.270^{\star \star \star}$ & 0.021 & $-0.028^{\star \star \star}$ & 0.002 & $0.209^{* * *}$ & 0.018 & $0.009^{* * *}$ & 0.001 & $-0.061^{* \star \star}$ & 0.004 & $-0.715^{\star \star \star}$ & 0.047 \\
\hline Loan book diversification & $0.069^{* * *}$ & 0.015 & $0.007^{\star \star *}$ & 0.002 & -0.001 & 0.011 & -0.001 & 0.001 & $0.025^{* \star *}$ & 0.004 & $-0.174^{* * *}$ & 0.051 \\
\hline NPL ratio & $-1.374^{\star * *}$ & 0.233 & $-0.124^{* * *}$ & 0.024 & $0.965^{* * *}$ & 0.170 & $0.079^{* * *}$ & 0.012 & $-0.314^{* * *}$ & 0.043 & $-3.579^{* * *}$ & 0.497 \\
\hline Tier 1 Ratio & -0.038 & 0.049 & $0.008^{\star}$ & 0.005 & $-0.116^{* * *}$ & 0.038 & $0.010^{* * *}$ & 0.004 & $0.026^{* *}$ & 0.011 & $0.879^{* \star \star}$ & 0.140 \\
\hline Inter-bank lending ratio & $-0.221^{\star \star \star}$ & 0.043 & $-0.026^{\star \star *}$ & 0.004 & $0.126^{\star \star \star}$ & 0.034 & $0.016^{\star \star \star}$ & 0.004 & $-0.104^{\star \star \star}$ & 0.010 & $-0.959^{\star \star \star}$ & 0.129 \\
\hline Short-term funding ratio & $-0.088^{* *}$ & 0.038 & $-0.010^{* * \star}$ & 0.003 & 0.048 & 0.031 & 0.003 & 0.002 & $-0.054^{* * *}$ & 0.010 & $-0.606^{* * *}$ & 0.106 \\
\hline Brokered deposits ratio & $-0.187^{\star \star \star}$ & 0.060 & $-0.015^{* * *}$ & 0.006 & $0.229^{* * *}$ & 0.050 & $0.020^{* * *}$ & 0.005 & $-0.038^{\star * \star}$ & 0.009 & $-0.453^{* * *}$ & 0.088 \\
\hline Dummy BHC with non-bank subs. & 0.017 & 0.015 & 0.0002 & 0.001 & -0.013 & 0.017 & 0.0002 & 0.001 & $-0.010^{* *}$ & 0.004 & $-0.086^{* *}$ & 0.041 \\
\hline Dummy stand-alone banks & $-0.009^{* \star}$ & 0.005 & $-0.001^{* *}$ & 0.0004 & -0.004 & 0.004 & -0.0003 & 0.0003 & $-0.004^{* * *}$ & 0.001 & $0.033^{\star *}$ & 0.016 \\
\hline Equity invested in NB subs & 0.004 & 0.068 & -0.0002 & 0.006 & -0.039 & 0.042 & -0.002 & 0.004 & 0.001 & 0.017 & -0.083 & 0.129 \\
\hline Balance due to NB subs & $-0.127^{\star \star *}$ & 0.024 & $-0.011^{* * *}$ & 0.002 & $0.118^{* * *}$ & 0.021 & $0.009^{* * *}$ & 0.002 & $-0.040^{* * *}$ & 0.005 & $-0.353^{* * *}$ & 0.051 \\
\hline Constant & 0.033 & 0.037 & 0.007 & 0.005 & $0.063^{* *}$ & 0.029 & 0.002 & 0.002 & $0.020^{* *}$ & 0.008 & $0.439^{* * \star}$ & 0.088 \\
\hline Observations & 6024 & & 6024 & & 6024 & & 6024 & & 5957 & & 5955 & \\
\hline R-squared, adjusted & 0.174 & & 0.191 & & 0.168 & & 0.175 & & 0.142 & & 0.144 & \\
\hline
\end{tabular}

Note: The regressors are averages over the period 2002-07, while the dependent variables are averages over 2008-12. For comparison, the results of specification 3 in Table 3 are reported in specifications 1. Robust standard errors are reported. $(* * *, * *, *)$ indicate significance on the 1,5 and 10 percent levels. 
Table 6: Disentangling the effect of non-traditional income sources, post-2006

\begin{tabular}{|c|c|c|c|c|c|c|c|c|c|c|c|c|c|c|c|c|}
\hline \multirow{3}{*}{ Performance measure Y(i): } & \multirow{2}{*}{\multicolumn{2}{|c|}{ Spec. 1}} & \multicolumn{2}{|c|}{ Spec. 2} & \multirow{2}{*}{\multicolumn{2}{|c|}{ Spec. 3}} & \multicolumn{2}{|c|}{ Spec. 4} & \multirow{2}{*}{\multicolumn{2}{|c|}{ Spec. 1}} & & ec. 2 & \multicolumn{2}{|c|}{ Spec. 3} & \multicolumn{2}{|c|}{ Spec. 4} \\
\hline & & & \multicolumn{4}{|c|}{$Y(i)=R O E(i)$} & & & & & \multicolumn{4}{|c|}{$Y(i)=$ volatility of $\operatorname{ROE}(\mathrm{i})$} & & \\
\hline & Coeff. & $\begin{array}{l}\text { Std. } \\
\text { dev. }\end{array}$ & Coeff. & $\begin{array}{l}\text { Std. } \\
\text { dev. }\end{array}$ & Coeff. & $\begin{array}{l}\text { Std. } \\
\text { dev. }\end{array}$ & Coeff. & $\begin{array}{l}\text { Std. } \\
\text { dev. }\end{array}$ & Coeff. & $\begin{array}{l}\text { Std. } \\
\text { dev. }\end{array}$ & Coeff. & $\begin{array}{l}\text { Std. } \\
\text { dev. }\end{array}$ & Coeff. & $\begin{array}{l}\text { Std. } \\
\text { dev. }\end{array}$ & Coeff. & $\begin{array}{l}\text { Std. } \\
\text { dev. }\end{array}$ \\
\hline Income diversification & 0.007 & 0.066 & 0.088 & 0.072 & -0.039 & 0.066 & 0.065 & 0.073 & $-0.180^{* * *}$ & 0.035 & $-0.182^{* * *}$ & 0.035 & $-0.176^{* * *}$ & 0.035 & $-0.181^{* * *}$ & 0.035 \\
\hline Income div., squared & 0.041 & 0.051 & -0.027 & 0.055 & 0.068 & 0.051 & -0.016 & 0.056 & $0.155^{* * *}$ & 0.027 & $0.148^{* \star *}$ & 0.027 & $0.151^{* * *}$ & 0.027 & $0.147^{* * *}$ & 0.027 \\
\hline Trading revenue & -0.020 & 0.252 & 0.129 & 0.305 & -0.060 & 0.224 & 0.202 & 0.316 & -0.144 & 0.141 & -0.037 & 0.123 & -0.126 & 0.135 & -0.079 & 0.116 \\
\hline Securities brokerage & 0.063 & 0.107 & 0.049 & 0.111 & 0.072 & 0.117 & 0.084 & 0.118 & -0.074 & 0.075 & -0.048 & 0.081 & -0.049 & 0.077 & -0.040 & 0.083 \\
\hline Investment banking & -0.048 & 0.059 & -0.064 & 0.054 & -0.051 & 0.066 & -0.110 & 0.077 & 0.026 & 0.026 & 0.039 & 0.026 & 0.004 & 0.037 & 0.037 & 0.041 \\
\hline Annuity sales & -0.209 & 0.415 & -0.154 & 0.391 & -0.261 & 0.423 & -0.153 & 0.399 & -0.159 & 0.224 & -0.102 & 0.215 & -0.112 & 0.215 & -0.077 & 0.212 \\
\hline Insurance underwriting & $0.602^{* *}$ & 0.302 & $0.634^{* *}$ & 0.285 & $0.576^{*}$ & 0.295 & $0.649^{* *}$ & 0.283 & $-0.245^{* *}$ & 0.108 & -0.168 & 0.134 & $-0.230^{* *}$ & 0.105 & -0.174 & 0.131 \\
\hline Insurance sale & $0.166^{* * *}$ & 0.031 & $0.152^{* * *}$ & 0.037 & $0.160^{* * *}$ & 0.031 & $0.150^{* * *}$ & 0.036 & -0.023 & 0.027 & -0.020 & 0.027 & -0.031 & 0.030 & -0.019 & 0.025 \\
\hline Venture capital & -0.340 & 1.168 & -0.267 & 1.291 & -0.212 & 1.184 & -0.079 & 1.272 & $1.124^{*}$ & 0.628 & $1.325^{*}$ & 0.684 & $1.061^{*}$ & 0.619 & $1.218^{*}$ & 0.679 \\
\hline Net servicing fees & $0.187^{* * *}$ & 0.044 & $0.167^{* * *}$ & 0.056 & $0.201^{* * *}$ & 0.040 & $0.177^{* * *}$ & 0.054 & $0.086^{* * *}$ & 0.026 & $0.095^{* * *}$ & 0.026 & $0.083^{* * *}$ & 0.026 & $0.090^{* * *}$ & 0.026 \\
\hline Net securitization income & $0.225^{* * *}$ & 0.042 & $0.221^{* * *}$ & 0.054 & $0.194^{* * *}$ & 0.051 & $0.178^{* * *}$ & 0.061 & 0.006 & 0.042 & 0.001 & 0.049 & 0.019 & 0.041 & 0.005 & 0.048 \\
\hline Other non-interest income & $0.098^{* * *}$ & 0.024 & $0.103^{* * *}$ & 0.026 & & & & & $0.061^{* * *}$ & 0.014 & $0.050^{* * *}$ & 0.014 & & & & \\
\hline Visa/debit card interchange fee & & & & & $0.010^{* * *}$ & 0.003 & $0.004^{* *}$ & 0.002 & & & & & 0.001 & 0.002 & $0.002^{* *}$ & 0.001 \\
\hline Merchant income & & & & & $0.005^{* * *}$ & 0.002 & $0.003^{* * *}$ & 0.001 & & & & & 0.001 & 0.002 & 0.002 & 0.001 \\
\hline Derivatives income & & & & & 0.002 & 0.003 & 0.002 & 0.002 & & & & & 0.001 & 0.002 & 0.001 & 0.001 \\
\hline Other fees (residual) & & & & & $-0.004^{* * * *}$ & 0.0013 & -0.001 & 0.001 & & & & & $0.002^{* *}$ & 0.001 & $0.002^{* * *}$ & 0.001 \\
\hline Intercompany fees & & & & & 0.003 & 0.002 & $0.004^{* * *}$ & 0.001 & & & & & 0.002 & 0.001 & 0.000 & 0.001 \\
\hline Affiliate services & & & & & 0.004 & 0.006 & 0.001 & 0.003 & & & & & -0.002 & 0.003 & -0.001 & 0.001 \\
\hline Debit card & & & & & $0.004^{* * *}$ & 0.001 & $0.006^{* * *}$ & 0.002 & & & & & $0.002^{* *}$ & 0.001 & 0.000 & 0.001 \\
\hline Withdrawal penalties & & & & & $-0.016^{* *}$ & 0.007 & $-0.012^{* * *}$ & 0.004 & & & & & 0.002 & 0.003 & 0.001 & 0.004 \\
\hline Royalty income & & & & & 0.005 & 0.004 & -0.003 & 0.007 & & & & & -0.003 & 0.002 & -0.002 & 0.002 \\
\hline Net gains on hedge & & & & & -0.002 & 0.003 & 0.002 & 0.003 & & & & & 0.003 & 0.002 & 0.001 & 0.001 \\
\hline Gain on sale & & & & & -0.001 & 0.001 & -0.000 & 0.002 & & & & & $0.002^{* * *}$ & 0.001 & $0.002^{* *}$ & 0.001 \\
\hline Mortgage origin. \& broker fees & & & & & $-0.008^{* * *}$ & 0.002 & $-0.010^{* * *}$ & 0.002 & & & & & $0.006^{* * *}$ & 0.001 & $0.003^{* * *}$ & 0.001 \\
\hline Operating leases & & & & & -0.002 & 0.002 & -0.001 & 0.002 & & & & & $0.004^{* * *}$ & 0.001 & $0.003^{*}$ & 0.002 \\
\hline Commissions & & & & & $0.003^{* *}$ & 0.001 & 0.002 & 0.001 & & & & & $-0.002^{* * *}$ & 0.001 & -0.001 & 0.000 \\
\hline Other services (residual) & & & & & -0.001 & 0.001 & 0.001 & 0.002 & & & & & $0.002^{* * *}$ & 0.001 & $0.002^{* * *}$ & 0.001 \\
\hline Legal settlements & & & & & $-0.008^{* *}$ & 0.004 & $-0.032^{* * * *}$ & 0.012 & & & & & 0.001 & 0.002 & $0.017^{* * *}$ & 0.006 \\
\hline Recoveries & & & & & -0.000 & 0.001 & $0.002^{*}$ & 0.001 & & & & & $0.001^{*}$ & 0.001 & 0.000 & 0.000 \\
\hline Management service fees & & & & & $-0.008^{*}$ & 0.004 & $-0.008^{*}$ & 0.004 & & & & & $0.009^{* * *}$ & 0.002 & 0.002 & 0.002 \\
\hline Yield spread & & & & & -0.004 & 0.005 & -0.005 & 0.010 & & & & & $-0.003^{*}$ & 0.002 & 0.0001 & 0.004 \\
\hline Wire transfer fees & & & & & $-0.007^{* *}$ & 0.003 & $-0.004^{* * * *}$ & 0.001 & & & & & $0.006^{* * *}$ & 0.002 & $0.002^{* * *}$ & 0.000 \\
\hline Visa fees and commissions & & & & & 0.004 & 0.003 & $0.009^{* *}$ & 0.004 & & & & & -0.002 & 0.002 & -0.004 & 0.002 \\
\hline Trust fees and income & & & & & 0.006 & 0.013 & -0.011 & 0.012 & & & & & $-0.011^{\star *}$ & 0.005 & $-0.009^{* *}$ & 0.004 \\
\hline Travelers check & & & & & $0.024^{* * *}$ & 0.009 & $0.039^{* * *}$ & 0.011 & & & & & -0.007 & 0.005 & -0.005 & 0.003 \\
\hline (Life) Insurance income & & & & & 0.001 & 0.001 & 0.000 & 0.001 & & & & & $0.001^{*}$ & 0.001 & $0.001^{* *}$ & 0.000 \\
\hline Dividend income & & & & & -0.014 & 0.011 & -0.031 & 0.029 & & & & & -0.003 & 0.005 & 0.010 & 0.012 \\
\hline Subsidiary income and fees & & & & & $0.005^{*}$ & 0.003 & 0.002 & 0.004 & & & & & -0.001 & 0.002 & 0.002 & 0.002 \\
\hline Tax refunds \& preparation fees & & & & & 0.000 & 0.002 & 0.005 & 0.004 & & & & & 0.002 & 0.002 & -0.001 & 0.002 \\
\hline ATM & & & & & -0.002 & 0.003 & -0.002 & 0.004 & & & & & $0.004^{*}$ & 0.002 & 0.002 & 0.002 \\
\hline Accounting fees & & & & & 0.001 & 0.004 & 0.001 & 0.005 & & & & & 0.002 & 0.002 & 0.002 & 0.003 \\
\hline Exchange and collection fees & & & & & -0.003 & 0.004 & -0.003 & 0.003 & & & & & $0.006^{* * *}$ & 0.002 & $0.005^{*}$ & 0.003 \\
\hline Letter of credit fees & & & & & $-0.052^{* * *}$ & 0.010 & $-0.057^{* \star *}$ & 0.015 & & & & & 0.008 & 0.006 & 0.016 & 0.010 \\
\hline Non-identified income & & & & & -0.000 & 0.001 & 0.000 & 0.002 & & & & & $0.001^{* * * *}$ & 0.000 & -0.000 & 0.001 \\
\hline Observations & 6024 & & 6024 & & 6024 & & 6024 & & 6024 & & 6024 & & 6024 & & 6024 & \\
\hline Control variables & Yes & & Yes & & Yes & & Yes & & Yes & & Yes & & Yes & & Yes & \\
\hline R-squared, adjusted & 0.244 & & 0.345 & & 0.256 & & 0.351 & & 0.361 & & 0.352 & & 0.372 & & 0.354 & \\
\hline
\end{tabular}

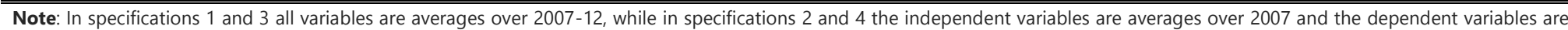

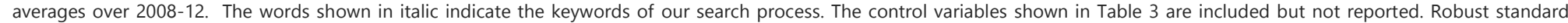
errors are reported. $\left({ }^{* \star *}, * *, *\right)$ indicate significance on the 1,5 and 10 percent levels. 